\title{
Tasarım Spektrumu Parametreleri için Olasılıksal Sismik Tehlike Analizlerine Bağlı Bir Çalışma
}

\author{
Özkan KALE ${ }^{1}$
}

ÖZ

Bu çalışma kapsamında tasarım spektrumu parametreleri (sabit ivme bölgesi köşe periyotları ve zemin faktörleri) Kuzey Anadolu Fay Hattı üzerinde seçilen bir bölge için yapılan olasılıksal sismik tehlike analizlerine bağlı olarak önerilmiştir. Sonuçlar farklı zemin türleri ve farklı dönüş periyotlarına göre elde edilmiştir. Olasılıksal sismik tehlike analizleri için alansal kaynak ve fay ve mekansal düzleştirilmiş kaynak model olmak üzere iki farklı sismik model kullanılmıştır. Yer hareketi karakterizasyonu bölgedeki sismik aktiviteyi en iyi şekilde temsil edebilecek yer hareketi tahmin denklemlerinin seçilmesiyle yapılmıştır. Sabit ivme bölgesi köşe periyotları ve zemin faktörlerinin hesabı PGA veya T = $0.2 \mathrm{~s}$ ve $1.0 \mathrm{~s}$ ' deki kaya zemin spektal ivme değerlerine bağlı olarak üretilen ampirik bağıntılara dayanmaktadır.

Anahtar Kelimeler: Olasılıksal sismik tehlike analizi, yer hareketi tahmin denklemi, tasarım spektrumu, kontrol periyotları, zemin faktörleri.

\begin{abstract}
A Study Depending on the Probabilistic Seismic Hazard Analyses for Design Spectrum Parameters

Within the scope of this study, design spectrum parameters (constant acceleration region, corner periods and site factors) are proposed, depending on probabilistic seismic hazard analyses conducted in a region located in a part of the North Anatolian Fault Zone. The outcomes are obtained for different site conditions and return periods. Two different seismic source models which are area based source, and fault and locational seismic source models are used for probabilistic seismic hazard analyses. The ground-motion characterization is handled by selecting the ground-motion prediction equations that best reflect the seismic excitations around the investigated region. The computation of constant acceleration region corner periods and site factors are based on the empirical relationships that depend on the PGA or spectral accelerations at $\mathrm{T}=0.2 \mathrm{~s}$ and $1.0 \mathrm{~s}$ for rock sites.
\end{abstract}

Keywords: Probabilistic seismic hazard analysis, ground-motion prediction equation, design spectrum, control periods, site factors.

\footnotetext{
Not: Bu yazı

- Yayın Kurulu'na 04.11.2015 günü ulaşmıştır.

- 31 Aralık 2017 gününe kadar tartışmaya açıktır.

- DOI: 10.18400/tekderg.331837
}

1 TED Üniversitesi, İnşaat Mühendisliği Bölümü, Ankara - ozkan.kale@tedu.edu.tr 
Tasarım Spektrumu Parametreleri için Olasılıksal Sismik Tehlike Analizlerine ...

\section{GíRiş̧}

Depreme dayanıklı yapı tasarımında, kuvvetli yer hareketi zorlaması altında bir yapıya etkiyecek olan deprem yüklerinin belirlenmesinde, deprem yönetmeliklerinde tanımlanan tasarım spektrumları kullanılmaktadır. Bir başka deyişle tasarım spektrumları, yapıların depreme dayanıklı olarak dizayn edilmesinde, binaların doğal titreşim periyoduna göre deprem etkisi altında maruz kalacakları yatay veya düșey yükleri belirlemede kullanılırlar. Spektrum eğrisi (tepki spektrumu), farklı doğal titreşim periyoduna sahip tek serbestlik dereceli sistemlerin, belirli bir sönüm oranı dikkate alınarak yer hareketi etkisi altında yapacakları en büyük davranış değerleri hesaplanarak elde edilir. Tasarım spektrumları ise bölgenin sismik özelliklerini ve zemin koşullarını dikkate alarak oluşabilecek maksimum deprem etkilerini göz önüne alabilmek için farklı yer hareketi ivme kayıtlarından hesaplanan tepki spektrumlarına düzgünleştirilmiş bir zarf eğrisi uydurulmasıyla elde edilmektedir. Bunun yanısıra daha özel tasarım gerektiren durumlarda sismik tehlike analizi sonucundan da tasarım spektrumları elde edilebilmektedir. Özellikle son yıllarda kuvvetli yer hareketi istasyonlarının sayısındaki artış beraberinde yer hareketi ivme kayıtlarının da artışını getirerek deprem tehlikesini tahmin etmeye yönelik araştırmalara yeni bir ufuk açmıştır. Sayısal verinin zenginleştirilmesini güvenilir zemin koşulu, sismik kaynak istasyon arası mesafe, fay türü gibi bilgilerin de iyileștirilmesi izlemiştir. Bu çalışmaların paralelinde türetilen yer hareketi tahmin denklemlerinin sayısında da artış olmuştur. Sonuç olarak da sismik tehlike analizlerinin popülaritesi artarak bu çalışmalardan daha güvenilir bilgiler alınmaya başlanmıştır.

Türk Deprem Yönetmeliği (TDY07; DBYBHY [1]), Eurocode-8 Avrupa Standardı (EC8; CEN [2]) ve NEHRP (National Earthquake Hazards Reduction Program) Amerikan Şartnamesi (BSSC [3]) kapsamında yer alan tasarım spektrumlarının genel görünüşü Şekil 1' de verilmektedir. Bu şekillerde, EC8 spektrumunda $T_{B}$ ve $T_{C}$ ve NEHRP spektrumunda $\mathrm{T}_{0}$ ve $\mathrm{T}_{\mathrm{S}}$ tasarım spektrumu köșe periyotlarını (sabit spektral ivme platosunun alt ve üst limit periyot değerlerini) gösterirken $T_{D}$ ve $T_{L}$ sabit yer değiştirme (veya uzun periyoda geçiş) bölgesinin (veya platosunun) başlangıç periyodunu temsil etmektedir. TDY07' de spektrum köşe periyotları sadece $T_{A}$ ve $T_{B}$ değerleri ile temsil edilirken sabit yer değiştirme bölgesine geçişte herhangi bir değişim dikkate alınmamaktadır. Sabit deplasman platosunun başlangıç noktasını tarif eden $T_{L}$ uzun periyotlu yapıların deplasman kontrollü tasarımları veya performans tahkikleri için spektral değerlerin hesaplanmasında önemli bir rol oynamaktadır ve bu periyottan sonra yer değiştirme istemi sabit kalmaktadır (Newmark ve Hall [4]). TDY07' de karșılaşılan bu durum doğal titreşim periyodu sabit yer değiștirme periyodundan daha büyük yapıların aşırı güvenli dizayn edilmesi sonucunu doğurmaktadır. Buna ek olarak TDY07 tasarım spektrumunda farklı zemin sinıflarının sabit ivme platosunun genliğine etkileri de dikkate alınmamaktadır.

EC8 tasarım spektrumunun mevcut durumunu iyileştirmek için yapılmış olan Rey vd. [5] çalışmasında Avrupa kuvvetli yer hareketi veri tabanındaki ivme kayıtları kullanılarak tepki spektrumları çıkarılmış ve sonrasında bunlar kayıtların mesafe bilgileriyle normalize edilmiştir.Elde edilen spektral ordinatlar kayıtların deprem katalog bilgileri gözetilerek deprem büyüklüğü ve zemin türlerine göre sınıflandırılarak tasarım spektrumu köșe periyotları ve kaya zemin sınıfı referans olmak üzere zemin amplifikasyon değerleri belirlenmiştir. Bu çalışma sonucunda EC8 spektrumunda spektral şekil ve zemin koşulları için köklü değişiklikler öngörülmüş ve sonrasında da EC8 spektrumu günümüzdeki haline 
dönüştürülmüştür. Kalkan ve Gülkan [6] çalışmasında Türkiye' de meydana gelmiş depremlerden derlenen bir veri seti kullanılarak zemin, mesafe ve deprem büyüklüğüne bağlı bir yer hareketi tahmin denklemi önerilmiş ve buna bağlı olarak bir dizayn spektrumu geliştirilerek Türk Deprem Yönetmeliği'nde tanımlanan spektrumla karşılaştırması yapılmıştır. Buradan seçilen deprem senaryosuna göre yönetmelik spektrumunun orta ve uzun periyot aralıklarında bu çalışmaya göre çok büyük değerler verdiği sonucuna ulaşılmıștır. Buna neden olarak yönetmelikte zemin koşullarına bağlı olarak tanımlanan sabit ivme platosunun fazla geniş olması gösterilmiştir. Ayrıca bu çalışmada zeminin yumuşamasına bağlı olarak zemin amplifikasyon etkileri de hesaplanmıştır. Pitilakis vd. [7] çalışmasında SHARE (Seismic Hazard Harmonization of the Europe, Giardini vd. [8]) projesi kapsamında derlenen global kuvvetli yer hareketi ivme kayıtları kullanılarak EC8 spektrumunun mevcut durumu ve farklı zemin koşulları için zemin faktörleri değerlendirilerek EC8' de tanımlanan spektrum için yeni zemin katsayıları önerilmiştir.

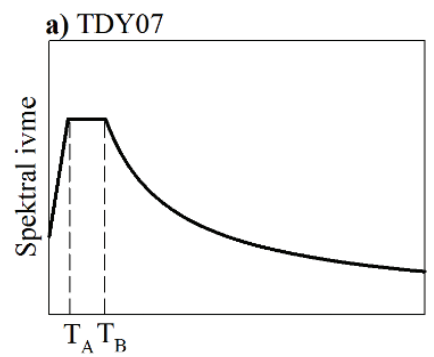

b) $\mathrm{EC} 8$

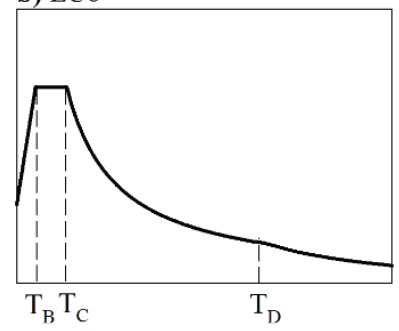

c) NEHRP

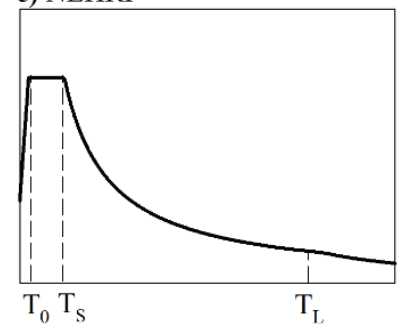

Şekil 1. İvme Tasarım Spektrumlarl: a) Türk Deprem Yönetmeliği (TDY07; DBYBHY [1]), b) Eurocode-8 Avrupa Standardl (EC8; CEN [2]) ve c) NEHRP Amerikan Şartnamesi (BSSC [3])

Seyhan ve Stewart [9] ise şu an kullanılmakta olan NEHRP Amerikan Şartnamesi' nin temelini oluşturan bir çalışmadır. Burada gözlemsel ve sentetik deprem kayıt setine bağlı olarak geliştirilen doğrusal olmayan zemin modeli yardımıyla spektral genlik ve zemin sınıfına bağlı olarak değişen zemin faktörleri kısa periyot (sabit ivme) ve orta-uzun periyot (sabit hız) bölgeleri için ayrı ayrı önerilmiştir. Bu çalışma da sabit ivme ve sabit hız bölgeleri sırasıyla $\mathrm{T}=0.1-0.5 \mathrm{~s}$ ve $0.4-2.0 \mathrm{~s}$ olarak hesaba katılmıştır. Bununla birlikte sabit ivme platosunun zemin sınıfına göre farklılık göstermesi hususu dikkate alınmamıştır. Şu an taslağı yayınlanan Türkiye Bina Deprem Yönetmeliği’ nde de (TBDY [10]) bu zemin faktörleri dikkate alınmaktadır. Bu zemin faktörleri şu an literatürdeki en güncel ve güvenilir olan bir çalışmanın ürünleri olmakla birlikte hem Amerikan Şartnamesi' nde hem de yürürlüğe girecek olan Türkiye Bina Deprem Yönetmeliği' nde bu faktörler kaya zemin için hesaplanan 2475 yıl dönüş periyoduna tekabül eden olasıllksal sismik tehlike hesabı tabanlı spektral değerlere uygulanmaktadır. Bu bağlamda, zemin faktörlerinin de sismik tehlike hesabının bir ürünü olmasının, farklı zemin sınıfları ve farklı dönüş periyotları için elde edilecek tasarım spektrumlarının güvenilirliğini de artırması beklenebilir.

Bu çalışmada kapsamında önceki paragrafta bahsedilen konunun detaylarını araştırabilmek amacıyla olasılıksal sismik tehlike analizlerinden elde edilen eşit (üniform) tehlike spektrumları kullanılmıştır. İlk aşamada olasılıksal sismik tehlike analizlerinin temel taşı 
Tasarım Spektrumu Parametreleri için Olasılıksal Sismik Tehlike Analizlerine ...

olan yer hareketi mantık ağacı uygulaması, çok sayıda yer hareketi tahmin denkleminin (YHTD) değerlendirilmesiyle oluşturulmuştur. Sonrasında seçilen sahaların farklı zemin türleri ve dönüş periyotları dikkate alınarak her bir grup için zarf eğrileri oturtulmak suretiyle sabit ivme platosu köşe periyotları ampirik bağıntıları elde edilmiştir. Son aşamada ise $\mathrm{V}_{\mathrm{S} 30}=760 \mathrm{~m} / \mathrm{s}$ değerindeki (kaya zemin için kesme dalgası hızı) spektral ivme değerleri referans alınmak üzere zemin faktörleri için ampirik bağıntılar önerilmiştir. Ampirik bağıntıların çıkarılmasında ivme platosu köşe periyotları her bir saha için zemin türü ve dönüş periyoduna bağlı olarak dikkate alınmıştır. Bu çalışmada köşe periyotları için kullanılan terminoloji, tasarım spekturumunun genel formu üzerinde $T_{0}$ ve $T_{S}$ ivme platosu başlangıç ve bitiş periyotlarını ve $T_{L}$ uzun periyot bölgesine geçiş periyodunu temsil edecek şekilde seçilmiştir (Şekil 1.c).

\section{YER HAREKETI TAHMIN DENKLEMLERİ VE OLASILIKSAL SISMIK TEHLIKE ANALIZLERI}

\subsection{Yer Hareketi Tahmin Denklemlerinin Test Edilmesi}

Sismik tehlike analizi yer hareketi mantık ağacı uygulamaları için 11 adet aktif sığ deprem tektoniği yapısına uygun aday yer hareketi tahmin denklemi seçilmiştir. Bu aday denklem grubunun belirlenmesinde öncelikli olarak literatürde yer alan yer hareketi tahmin denklemleri belirlenmiştir. Sonrasında bu denklemler arasından, Cotton vd. [11] ve Bommer vd. [12] çalışmalarında verilen ön seçim kriterleri göz önüne alınarak çalışma bölgesi için uygun olan aday denklemler seçilmiştir. Bu tahmin denklemlerinin kısaltmaları ve genel özellikleri Tablo 1' de listelenmiştir. Bu listede Türk veri tabanından farklı zamanlarda türetilmiş 3 adet yer hareketi tahmin denklemi (KG04, Ozb04, KAAH15) yer almaktadır. Diğer denklemler Avrupa ve Orta Doğu (ASB14, Bnd14), Batı Amerika ve Tayvan (AS08, BA08, CB08, CY08) ve Japonya (CF08, Zh06) deprem kayıtlarının kullanılarak türetildiği yer hareketi tahmin denklemleridir.

Aday denklemler veri bazlı çalışan test yöntemlerinden Nash ve Sutcliffe Etkinlik Katsayısı (NSE; Nash ve Sutcliffe [23]), Olabilirlik Yöntemi (LH; Scherbaum vd. [24]), Logaritmik Olabilirlik Yöntemi (LLH; Scherbaum vd. [25]) ve Öklid Uzaklığına Dayalı Sıralama Yöntemi (EDR; Kale ve Akkar [26]) kullanılarak test edilmiştir. Testlerin yapılabilmesi için gerekli kuvvetli yer hareketi veri tabanı Danciu vd. [27] çalışmasında derlenen Türkiye' ye ait veri tabanıdır. Şekil 2' de veri tabanındaki ivme kayıtlarının Joyner-Boore mesafelerine $\left(\mathrm{R}_{\mathrm{JB}}\right)$ karşılık gelen moment magnitüd $\left(\mathrm{M}_{\mathrm{w}}\right)$ dağılımları fay türleri (normal, $\mathrm{N}$; ters, T; doğrultu atımlı, S) ve zemin sınıfları gözetilerek gösterilmiştir. Fay türleri ve zemin sınıflarında yer alan kayıtlara ait sayısal bilgi şekillerin açıklama bölümünde parantez içinde belirtilmiş̧ir. Zemin sınıflarında yumuşak zemin $V_{\text {S30 }}<360 \mathrm{~m} / \mathrm{s}$, sert zemin $360 \leq$ $\mathrm{V}_{\mathrm{S} 30}<760 \mathrm{~m} / \mathrm{s}$ ve kaya zemin de $\mathrm{V}_{\mathrm{S} 30} \geq 760 \mathrm{~m} / \mathrm{s}$ olarak temsil edilmiştir.

$\mathrm{Bu}$ çalışmada kullanılan istatistiki test yöntemlerinden LH yöntemi, normalize edilmiş artıkların aşılma olasılıklarını hesaplayarak medyan aşılma olasılığı değerini sıralamada kullanılacak LH indeksi olarak vermektedir. LH indeksi için 0.5 ve üzeri değerler, modelin veri seti üzerinde iyi performans gösterdiği anlamını taşımaktadır. LLH yöntemi, yer hareketi tahmin denklemini olasılık dağılımı olarak alır ve gözlemsel verinin bu dağılımda karşılık gelen olabilirliğini hesaplar. Bütün veri seti için elde edilen olabilirlik değerlerinin ortalaması LLH indeksi olarak rapor edilir. Küçük LLH değerleri denklemin seçilen veri 
tabanı üzerinde iyi performans gösterdiği anlamına gelmektedir. NSE yöntemi modeldeki yanlılığ hesaplamaktadır ve $-\infty$ ile 1 arasında ( 1 en iyi performans düzeyini gösterir) değerler almaktadır. EDR yönteminde gözlemsel veri ile modelin \pm 3 standart sapma bandındaki farkları dikkate alınarak bunların olasılık tabanlı ortalamaları değiştirilmiş öklid

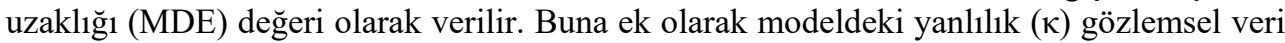
ile medyan tahminler arasındaki eğilime göre hesaplanarak bu iki bileşenden (MDE ve $\kappa$ ) EDR siralama indeksi rapor edilmektedir.

Tablo 1. Aday Yer Hareketi Tahmin Denklemleri ve Bunların Genel Özellikleri

\begin{tabular}{|c|c|c|c|c|c|c|c|}
\hline $\begin{array}{c}\text { Tahmin } \\
\text { Denklemi }\end{array}$ & Kisaltma & $\begin{array}{c}\text { Ana } \\
\text { Bölge(ler) }\end{array}$ & $\begin{array}{c}\mathbf{N}_{\text {kayit }} \\
\mathbf{N}_{\text {deprem }}\end{array}$ & $\underset{\operatorname{aralık}^{+}}{\mathbf{M}_{\mathbf{w}}}$ & $\begin{array}{c}\text { Mesafe türü } \\
\mathbf{R}_{\max }{ }^{*}\end{array}$ & $\begin{array}{c}\text { Fay } \\
\text { türü̈ }^{\#}\end{array}$ & $\begin{array}{l}\text { Zemin } \\
\text { etkisi }\end{array}$ \\
\hline $\begin{array}{l}\text { Kalkan ve } \\
\text { Gülkan [6] }\end{array}$ & KG04 & Türkiye & $\begin{array}{c}112 \\
57\end{array}$ & $4.0-7.4$ & $\begin{array}{c}\mathrm{R}_{\mathrm{JB}} \\
250 \mathrm{~km}\end{array}$ & $\mathrm{U}$ & $\mathrm{V}_{\mathrm{S} 30}$ \\
\hline $\begin{array}{c}\text { Özbey vd. } \\
\text { [13] }\end{array}$ & Ozb04 & $\begin{array}{l}\text { Kuzeybatı } \\
\text { Türkiye }\end{array}$ & $\begin{array}{c}195 \\
17\end{array}$ & $5.0-7.4$ & $\begin{array}{c}\mathrm{R}_{\mathrm{JB}} \\
300 \mathrm{~km}\end{array}$ & $\mathrm{U}$ & $\begin{array}{c}\text { Model } \\
\text { değişkeni }\end{array}$ \\
\hline Zhao vd. [14] & Zh06 & Japonya & $\begin{array}{c}4726 \\
269\end{array}$ & $5.0-8.3$ & $\begin{array}{c}\mathrm{R}_{\mathrm{RUP}} \\
300 \mathrm{~km}\end{array}$ & $\mathrm{~S}, \mathrm{~N}, \mathrm{R}$ & $\begin{array}{c}\text { Model } \\
\text { değişkeni }\end{array}$ \\
\hline $\begin{array}{c}\text { Cauzzi ve } \\
\text { Faccioli }[15]\end{array}$ & CF08 & Japonya & $\begin{array}{c}1164 \\
60\end{array}$ & $5.0-7.2$ & $\begin{array}{c}\mathrm{R}_{\mathrm{RUP}} \\
150 \mathrm{~km}\end{array}$ & $\mathrm{~S}, \mathrm{~N}, \mathrm{R}$ & $\begin{array}{c}\text { Model } \\
\text { değişkeni }\end{array}$ \\
\hline $\begin{array}{l}\text { Abrahamson } \\
\text { ve Silva [16] }\end{array}$ & AS08 & $\begin{array}{c}\text { Amerika ve } \\
\text { Tayvan }\end{array}$ & $\begin{array}{c}2754 \\
135\end{array}$ & $5.0-8.5$ & $\begin{array}{c}\mathrm{R}_{\text {RUP }} \\
200 \mathrm{~km}\end{array}$ & $\mathrm{~S}, \mathrm{~N}, \mathrm{R}$ & $\mathrm{V}_{\mathrm{S} 30}$ \\
\hline $\begin{array}{c}\text { Boore ve } \\
\text { Atkinson [17] }\end{array}$ & BA08 & $\begin{array}{c}\text { Amerika ve } \\
\text { Tayvan }\end{array}$ & $\begin{array}{c}1574 \\
58\end{array}$ & $5.0-8.0$ & $\begin{array}{c}\mathrm{R}_{\mathrm{JB}} \\
200 \mathrm{~km}\end{array}$ & $\mathrm{~S}, \mathrm{~N}, \mathrm{R}$ & $\mathrm{V}_{\mathrm{S} 30}$ \\
\hline $\begin{array}{c}\text { Campbell ve } \\
\text { Bozorgnia } \\
{[18]}\end{array}$ & CB08 & $\begin{array}{c}\text { Amerika ve } \\
\text { Tayvan }\end{array}$ & $\begin{array}{c}1561 \\
64\end{array}$ & $4.0-8.5$ & $\begin{array}{c}\mathrm{R}_{\text {RUP }} \\
200 \mathrm{~km}\end{array}$ & $\mathrm{~S}, \mathrm{~N}, \mathrm{R}$ & $\mathrm{V}_{\mathrm{S} 30}$ \\
\hline $\begin{array}{c}\text { Chiou ve } \\
\text { Youngs [19] }\end{array}$ & CY08 & $\begin{array}{c}\text { Amerika ve } \\
\text { Tayvan }\end{array}$ & $\begin{array}{c}1950 \\
125\end{array}$ & $4.0-8.5$ & $\begin{array}{c}R_{\text {RUP }} \\
200 \mathrm{~km}\end{array}$ & $\mathrm{~S}, \mathrm{~N}, \mathrm{R}$ & $\mathrm{V}_{\mathrm{S} 30}$ \\
\hline $\begin{array}{l}\text { Akkar vd. } \\
{[20]}\end{array}$ & ASB14 & $\begin{array}{l}\text { Avrupa ve } \\
\text { Orta Doğu }\end{array}$ & $\begin{array}{c}1041 \\
221\end{array}$ & $4.0-8.0$ & $\begin{array}{c}\mathrm{R}_{\mathrm{JB}} \\
200 \mathrm{~km}\end{array}$ & $\mathrm{~S}, \mathrm{~N}, \mathrm{R}$ & $\mathrm{V}_{\mathrm{S} 30}$ \\
\hline Bindi vd. [21] & Bnd14 & $\begin{array}{l}\text { Avrupa ve } \\
\text { Orta Doğu }\end{array}$ & $\begin{array}{c}2126 \\
365\end{array}$ & $4.0-7.6$ & $\begin{array}{c}\mathrm{R}_{\mathrm{JB}} \\
300 \mathrm{~km}\end{array}$ & $\mathrm{~S}, \mathrm{~N}, \mathrm{R}$ & $\mathrm{V}_{\mathrm{S} 30}$ \\
\hline Kale vd. [22] & KAAH15 & Türkiye & $\begin{array}{l}670 \\
175\end{array}$ & $4.0-8.0$ & $\begin{array}{c}R_{\mathrm{JB}} \\
200 \mathrm{~km}\end{array}$ & $\mathrm{~S}, \mathrm{~N}, \mathrm{R}$ & $\mathrm{V}_{\mathrm{S} 30}$ \\
\hline
\end{tabular}

${ }^{*} \mathrm{~N}_{\text {kayt }}$ : kuvvetli yer hareketi ivme kaydı sayısı, $\mathrm{N}_{\text {deprem}}$ : deprem sayısı

${ }^{+} \mathrm{M}_{\mathrm{w}}$ : moment magnitüd

${ }^{\ddagger} \mathrm{R}_{\mathrm{JB}}$ : Joyner-Boore mesafesi, $\mathrm{R}_{\max }$ : maksimum mesafe, $\mathrm{R}_{\mathrm{RUP}}$ : fay kırığına en yakın mesafe

${ }^{\#} \mathrm{~N}$ : normal fay, R: ters fay, S: doğrultu atımlı fay, U: tanımlanmamış fay

Şekil 3 aday tahmin denklemlerinin Türkiye kuvvetli yer hareketi veri tabanı kullanılarak model performanslarının değerlendirme sonuçlarını göstermektedir. Bu şekilde kullanılan formata göre üst satırda EDR ve NSE indekslerinin, alt satırda ise LH ve LLH indekslerinin seçilen periyot aralığındaki değiş̧imleri verilmiştir. YHTD' lerin değerlendirildiği periyot aralığı $\mathrm{T}=0-4 \mathrm{~s}$ arasındadır ve seçilen 10 ayrı periyot değerinde tahmin denklemleri test edilmiştir. Seçilen değerler T $=0 \mathrm{~s}, 0.1 \mathrm{~s}, 0.2 \mathrm{~s}, 0.5 \mathrm{~s}, 0.75 \mathrm{~s}, 1.0 \mathrm{~s}, 1.5 \mathrm{~s}, 2.0 \mathrm{~s}, 3.0 \mathrm{~s}, 4.0 \mathrm{~s}$ ' 
Tasarım Spektrumu Parametreleri için Olasılıksal Sismik Tehlike Analizlerine ...

dir ve $\mathrm{T}=0 \mathrm{~s}$ maksimum yer ivmesini (PGA) temsil etmektedir. Burada listelenen periyot değerlerinin seçimi sismik tehlike analizlerinin yapılacağı periyot bandını kapsayacak şekilde yapılmıştır. Tablo 2' de ise Şekil 3' de verilen her bir YHTD' ye ait test skorlarının seçilen periyot aralığındaki ortalama değerleri listelenmiştir. Bu tablolarda listede en üstte yer alan tahmin denkleminin o yönteme göre çalışmada kullanılan veri tabanını en iyi şekilde temsil ettiği söylenebilmektedir. Bu tablolarda farklı test yöntemleri için verilen siralamalar incelendiğinde test yöntemlerinin uygulanması sonucunda KAAH15, ASB14, Bnd14, Zh06, CF08 ve CY08 tahmin denklemlerinin çalışmada kullanılan kuvvetli yer hareketi veri tabanını daha iyi temsil ettiği sonucunu çıkarmak mümkündür.
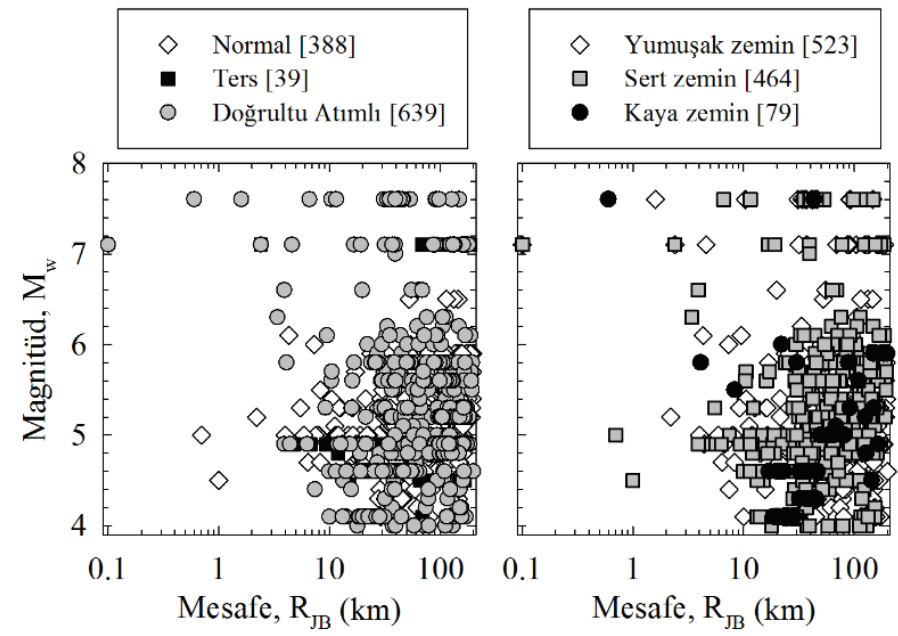

Şekil 2. Türkiye Kuvvetli Yer Hareketi Veri Tabanının Fay Türü ve Zemin Sinıfi Cinsinden Mesafeye $\left(R_{J B}\right)$ Karşıllk Moment Magnitüd $\left(M_{w}\right)$ Dağıllimları

Aday YHTD’ lerin veri bazlı test yöntemlerine göre yapılan değerlendirmelerinden sonra tahmin denklemlerine ait ivme spektrumu trelis (çapraz) diyagramları (farklı mesafe, magnitüd, fay türü v.b. özellikler dikkate alınarak elde edilen şekiller kümesi) dikkate alınarak aday denklemlerin genel davranışları değerlendirilmiştir. Projede dikkate alınan bölgeye sismik kaynaklardan gelebilecek etkileri göz önüne almak üzere seçilen magnitüd $\mathrm{M}_{\mathrm{w}}=5.0, \mathrm{M}_{\mathrm{w}}=6.0, \mathrm{M}_{\mathrm{w}}=7.0$ ve $\mathrm{M}_{\mathrm{w}}=8.0$ ve mesafe $\mathrm{R}_{\mathrm{JB}}=2.5 \mathrm{~km}, \mathrm{R}_{\mathrm{JB}}=50 \mathrm{~km}$ ve $\mathrm{R}_{\mathrm{JB}}=100$ $\mathrm{km}$ için elde edilen trelis şekilleri Şekil 4' de YHTD' lerin medyan tahmin değerleri için gösterilmiştir. Periyot aralığı olarak önceki bölümde veri bazlı test yöntemleri için de seçilen $\mathrm{T}=0$ - $4 \mathrm{~s}$ arası baz alınmıştır. Aday denklemlerden Bnd14 $\mathrm{T}=3 \mathrm{~s}$ 'den sonrası için tahmin yapmaya uygun olmadığı için bu denkleme ait spektrumlar sınır periyot değerine kadar çıkarılmıştır. Ele alınan deprem senaryolarında, fay türü olarak doğrultu atımlı fay ve zemin türü olarak da $\mathrm{V}_{\mathrm{S} 30}=760 \mathrm{~m} / \mathrm{s}$ (kaya zemin) değeri dikkate alınmıştır. Farklı deprem senaryoları trelis şekillerinden çıkarılan ilk sonuç CF08 ve Zh06 modellerinin ürettiği tahminlerin diğer modellere göre daha büyük olduğudur. Bnd14 modeli de büyük magnitüd ve yakın mesafe tahminlerinde çok büyük değerler vermektedir. KAAH15 ve ASB14 denklemlerinin medyan tahminleri özellikle de büyük magnitüdlerde birbirine oldukça yakındır. Diğer zemin türlerine ait senaryolar için de benzer gözlemler yapılmıştır. 


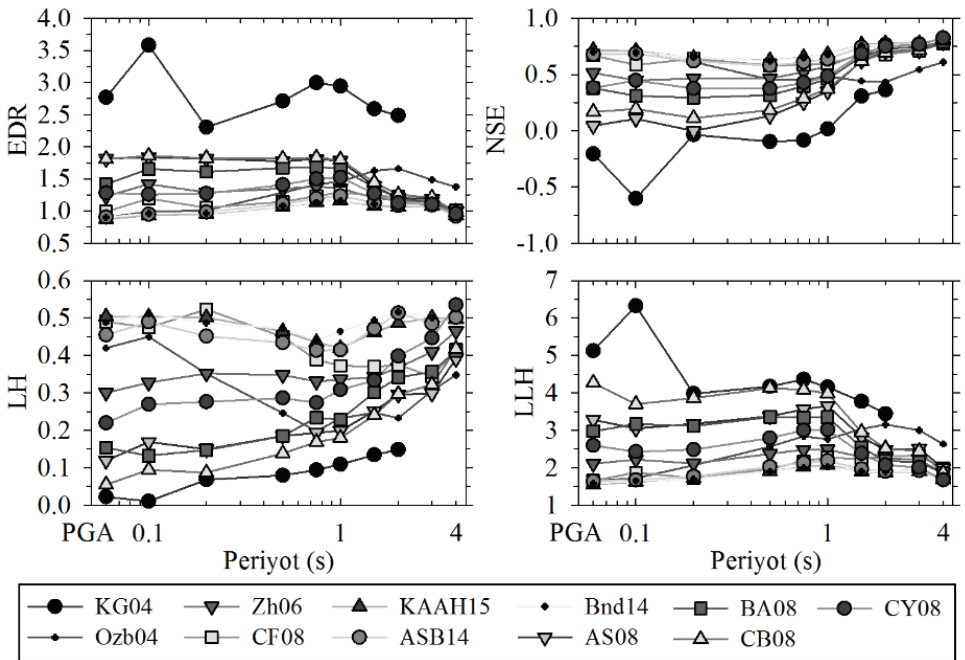

Şekil 3. Yer Hareketi Tahmin Denklemlerinin Seçilen Periyotlardaki Test Sonuçları

Tablo 2. Model Performanslarının Türkiye Veri Tabanına Göre Seçilen Periyot Aralığındaki Ortalama Değerleri

\begin{tabular}{|c|c|c|}
\hline EDR - Sira & YHTD & Skor \\
\hline 1 & KAAH15 & 1.029 \\
\hline 2 & Bnd14 & 1.056 \\
\hline 3 & ASB14 & 1.060 \\
\hline 4 & CF08 & 1.152 \\
\hline 5 & Zh06 & 1.251 \\
\hline 6 & CY08 & 1.270 \\
\hline 7 & Ozb04 & 1.321 \\
\hline 8 & BA08 & 1.441 \\
\hline 9 & AS08 & 1.562 \\
\hline 10 & CB08 & 1.583 \\
\hline 11 & KG04 & 2.798 \\
\hline
\end{tabular}

\begin{tabular}{|c|c|c|}
\hline NSE - Sira & YHTD & Skor \\
\hline 1 & KAAH15 & 0.717 \\
\hline 2 & Bnd14 & 0.699 \\
\hline 3 & ASB14 & 0.691 \\
\hline 4 & CF08 & 0.650 \\
\hline 5 & Zh06 & 0.590 \\
\hline 6 & CY08 & 0.552 \\
\hline 7 & Ozb04 & 0.542 \\
\hline 8 & BA08 & 0.509 \\
\hline 9 & CB08 & 0.415 \\
\hline 10 & AS08 & 0.371 \\
\hline 11 & KG04 & -0.043 \\
\hline
\end{tabular}

\begin{tabular}{|c|c|c|}
\hline LH - Sira & YHTD & Skor \\
\hline 1 & Bnd14 & 0.486 \\
\hline 2 & KAAH15 & 0.477 \\
\hline 3 & ASB14 & 0.463 \\
\hline 4 & CF08 & 0.420 \\
\hline 5 & Zh06 & 0.358 \\
\hline 6 & CY08 & 0.335 \\
\hline 7 & Ozb04 & 0.303 \\
\hline 8 & BA08 & 0.249 \\
\hline 9 & AS08 & 0.225 \\
\hline 10 & CB08 & 0.200 \\
\hline 11 & KG04 & 0.084 \\
\hline
\end{tabular}

\begin{tabular}{|c|c|c|}
\hline LLH - Sira & YHTD & Skor \\
\hline 1 & KAAH15 & 1.830 \\
\hline 2 & Bnd14 & 1.845 \\
\hline 3 & ASB14 & 1.893 \\
\hline 4 & CF08 & 2.056 \\
\hline 5 & Zh06 & 2.242 \\
\hline 6 & CY08 & 2.449 \\
\hline 7 & Ozb04 & 2.546 \\
\hline 8 & BA08 & 2.806 \\
\hline 9 & AS08 & 2.992 \\
\hline 10 & CB08 & 3.381 \\
\hline 11 & KG04 & 4.416 \\
\hline
\end{tabular}


Tasarım Spektrumu Parametreleri için Olasılıksal Sismik Tehlike Analizlerine ...

$\mathrm{Bu}$ gözlemlerden hareketle yer hareketi tahminlerindeki modelleme belirsizliğini dikkate alabilmek için maksimum, medyan ve minimum davranışı temsil edecek denklemlerin mantık ağacı uygulamasına seçilmesi uygun görülmektedir (Stewart vd. [28]). Maksimum davranışı temsil eden denklemlerden CF08 modelinin sismik tehlike analizi sonuçlarını ciddi ölçüde artırdığı bilinmektedir (Danciu vd. [27]). Bu nedenle Zh06 modeli maksimum davranışı temsil edecek denklem olarak seçilmiştir. Medyan davranış CY08 ve ASB14 denklemleriyle temsil edilirken Bnd14 denklemi kritik spekral periyot bantlarındaki çok yüksek değerleri nedeniyle sonraki aşamada dikkate alınmamıştır. Minimum davranış ise KAAH15 yer hareketi tahmin denklemi ile temsil edilmiştir. Seçilen bu 4 denkleme ait mantık ağacı uygulaması ağırlıkları ise sonraki aşamada sismik tehlike hassaslık analizleri yöntemi (Kale ve Akkar [29, 30]) ile belirlenmiştir.
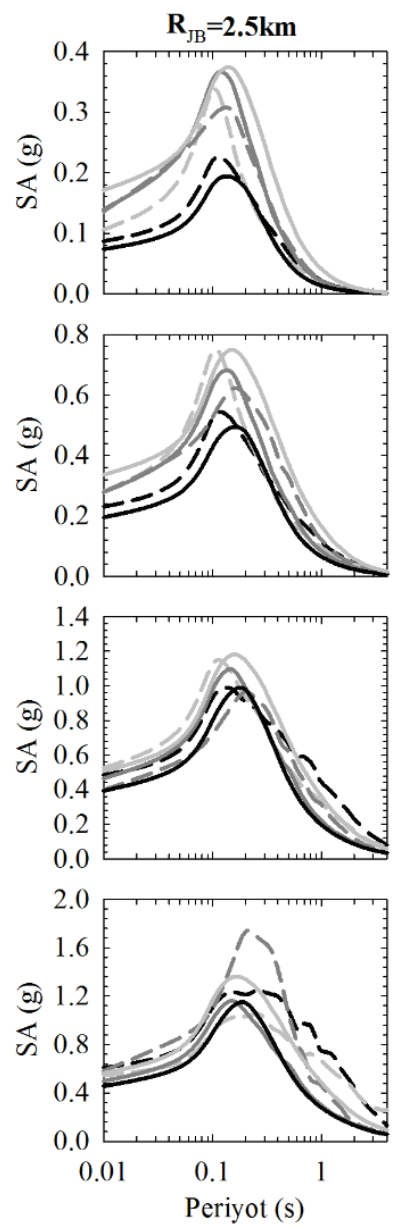
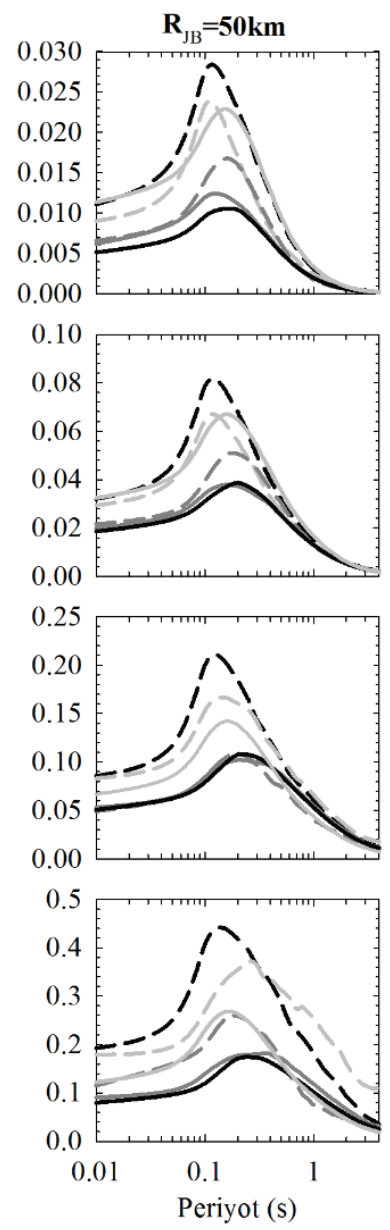
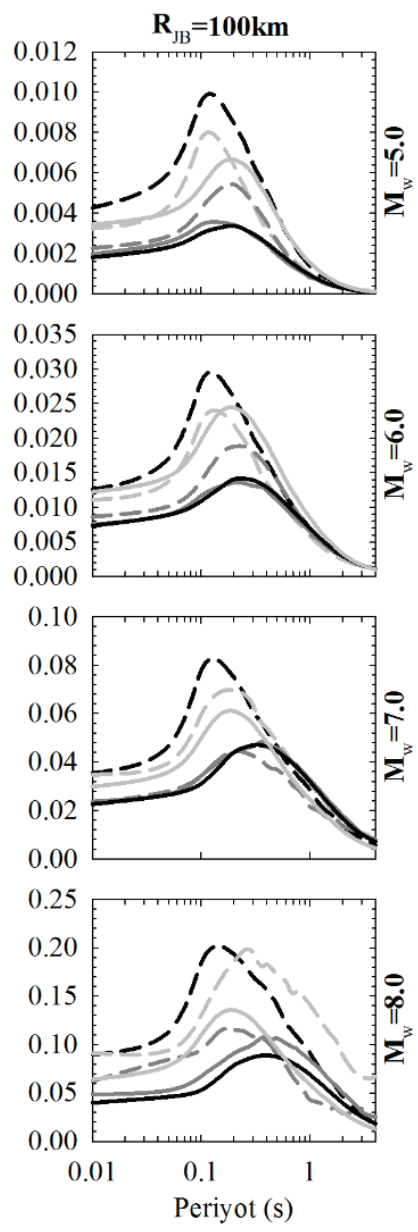

$$
\begin{array}{rllllll}
\hline \text { ASB14 } & --- & \text { Bnd14 - - CF08 KAAH15 } & \text { CY08 } & \text { C } & \text { Zh06 } \\
\hline
\end{array}
$$

Şekil 4. Seçilen Denklemlere Ait Tepki Spektrumu Medyan Trelis Diyagramı $\left(V_{S 30}=760\right.$ $\mathrm{m} / \mathrm{s}$, Doğrultu Atıml Fay) 


\subsection{Yer Hareketi Mantık Ağacı Uygulaması}

YHTD' lerin seçilmesi çalışmalarının son etabında nihai mantık ağacı uygulamasını oluşturacak denklem seti ve bunlara ait ağırlıkların belirlenebilmesi için Kale ve Akkar [29, 30] çalışmasında önerilen mantık ağacı hassaslık analizleri yöntemi kullanılmıştır. $\mathrm{Bu}$ yönteme göre aday denklemlerden iyi performans gösterenler kullanılarak farklı gruplar oluşturulmaktadır. Daha sonra denklemlere farklı ağıllıklar atanarak bu grupların alt grupları oluşturulmaktadır. Böylece model belirsizliği, oluşturulan M sayıda mantık ağacı uygulamasıyla tanımlanmış olmaktadır. Bu mantık ağacı uygulamalarına ait tehlike eğrileri çalışma bölgesindeki her bir saha ve dikkate alınan her bir periyot değerinde elde edilerek seçilen dönüş periyotlarına göre medyan trendi veren mantık ağacı uygulaması belirlenmektedir. Son olarak bütün periyotlardaki sonuçlar değerlendirilerek nihai mantık ağacı uygulamasına ulaşılmaktadır. Bu yöntemin uygulanmasındaki ana amaç seçilen mantık ağacı uygulamasında yer alan herhangi bir yer hareketi tahmin denkleminin olasılıksal sismik tehlike analizi sonuçlarını azaltıcı veya artıııı yönde yönlendirmesini önlemektir.

Önceki paragrafta özetlenen yönteme göre ASB14, CY08, KAAH15 ve Zh06 denklemlerinin üçlü ve dörtlü grupları oluşturulmuş ve bunlara farklı ağırlık şablonları atanarak toplam 144 adet mantık ağacı uygulaması elde edilmiştir. Sonrasında bunlar içinden tekrarlanan mantık ağacı uygulamaları ve Zh06 denkleminin \%50 ağırlık aldığı durumlar listeden çıkarılmıştır. Sonuç olarak sismik tehlike hassaslık analizlerinde kullanılabilecek nitelikte olan 39 farklı mantık ağacı uygulaması elde edilmiştir. Detayları sonraki bölümde verilecek olan olasıllksal sismik tehlike analizleri sonucunda her bir denklem için hesaplanan tehlike eğrileri, oluşturulan mantık ağacı uygulamalarındaki yer hareketi tahmin denklemleri ve bunların ağıllıklarına göre birleştirilerek proje bölgesindeki her bir saha için 39 farklı tehlike eğrisi elde edilmiştir. Sonrasında bu tehlike eğrileri kullanılarak seçilen spektral periyot değerleri ( $\mathrm{PGA}, \mathrm{T}=0.2 \mathrm{~s}$ ve $\mathrm{T}=1.0 \mathrm{~s}$ ) ve dönüş periyotları $\left(T_{R}=72\right.$ yıl, $475 \mathrm{yll}, 2475$ yıl $)$ için değerlendirmeler yapılarak proje bölgesi için en uygun yer hareketi mantık ağacı uygulaması KAAH15, ASB14, CY08 ve Zh06 yer hareketi tahmin denklemlerinin sırasıyla $0.30,0.30,0.30$ ve 0.10 ağırlıklarıyla oluşturulmuştur.

\subsection{Olasılıksal Sismik Tehlike Analizleri}

Olasılıksal sismik tehlike analizlerinde kullanılacak olan sismik kaynak modelleri Sesetyan vd. [31] ve Demircioğlu vd. [32] çalışmalarına göre oluşturulmuştur. Burada bölge alan kaynak (Sesetyan vd. [31]) ve çizgisel (fay) ve mekansal düzleştirilmiş kaynak (Demircioğlu vd. [32]) model olmak üzere iki farklı şekilde modellenmiştir. Bu çalışma kapsamında olasılıksal sismik tehlike analizlerinin yapılacağı bölge olarak Kuzey Anadolu Fay Hattı (KAF) üzerinde bir alan seçilmiştir. Bu alan içinde olasılıksal sismik tehlike analiz sonuçları $0.2^{\circ} \times 0.2^{\circ}$ lik enlem ve boylam aralıklarıyla toplam 224 nokta için elde edilmiştir. Proje kapsamında seçilen çalışma bölgesi ve sismik kaynaklar Şekil 5' de gösterilmiştir. Çalışma alanının seçimi yapılırken analizler için gerekli zaman ve hesaplama altyapısı da düşünülerek hem sismik aktivitenin yoğun olduğu faya yakın yerlerde hem de seçilen bölgenin kuzeydoğu ve güneybatı bölümlerinde ana faya uzak daha düşük sismik aktivite seviyeleri için sonuç alınabilmesi durumları göz önünde bulundurulmuştur. Türkiye' deki sismik aktivitenin önemli bir kısmının doğrultu atımlı fay mekanizmasında 
Tasarım Spektrumu Parametreleri için Olasılıksal Sismik Tehlike Analizlerine ...

gerçekleştiği düşünülürse seçilen bölgenin bu çalışma kapsamında yapılan değerlerdirmeler için uygun olduğu sonucuna ulaşılabilir.

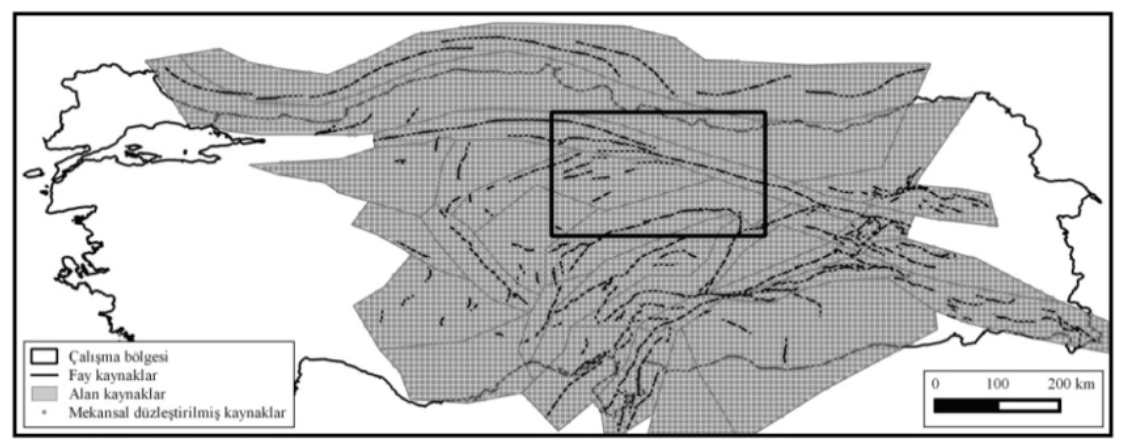

Şekil 5. Olasılıksal Sismik Tehlike Analizleri için Seçilen Çalışma Bölgesi ve Sismik Kaynaklar

Olasıllksal sismik tehlike analizleri EZ-FRisk programında (Risk Engineering [33]) yapılmıştır. Tehlike hesapları alansal kaynak modeli için ayrı, çizgisel (fay) ve mekansal düzleştirilmiş kaynak modeli için ayrı yapılmış ve bunların sonuçları eşit ağırlıklar (\%50 \%50) verilerek birleştirilmiştir. Analiz sonuçlarında zemin etkilerini gözetebilmek için analzilerde kaya, sert, yumuşak ve çok yumuşak zemin sınıfları sırasıyla $V_{\mathrm{S} 30}=760 \mathrm{~m} / \mathrm{s}$, $520 \mathrm{~m} / \mathrm{s}, 255 \mathrm{~m} / \mathrm{s}$ ve $180 \mathrm{~m} / \mathrm{s}$ değerleri ile temsil edilmiştir. Sismik tehlike analizleri PGA ve $\mathrm{T}=0.03 \mathrm{~s}$ ile $\mathrm{T}=4.0 \mathrm{~s}$ arasında seçilen 26 farklı periyot değeri için yapılmıştır. Bu analizler sonucunda elde edilen sahaya özel olasılıksal sismik tehlike eğrileri kullanılarak 3 farklı dönüş periyoduna ( $T_{R}=72$ yıl, 475 yıl ve 2475 yll) göre olasılıksal sismik tehlike tabanlı ivme spektrumları (eşit tehlike spektrumları) çıkarılmıştır.

\section{TASARIM SPEKTRUMU KÖŞE PERIYOTLARININ BELIRLENMESI}

Eşit tehlike spektrumları kullanılarak çıkarılacak olan tasarım spektrumu ivme platosu köşe periyotlarının $\left(\mathrm{T}_{0}\right.$ ve $\left.\mathrm{T}_{\mathrm{S}}\right)$ belirlenmesi için NEHRP (BSSC [3]) şartnamesinde tanımlanan yöntem dikkate alınmıştır. NEHRP şartnamesindeki tanıma göre ivme platosunun bitiş periyodu $\left(T_{S}\right) T=1.0 \mathrm{~s}$ ' deki spektral ivme değerinin $\left(\mathrm{SA}_{1.0}\right) \mathrm{T}=0.2 \mathrm{~s}$ ' deki spektral ivme değerine $\left(\mathrm{SA}_{0.2}\right)$ oranı olarak hesaplanmaktadır (Denklem 1.a). Burada $\mathrm{SA}_{0.2}$ kısa periyot ivme değerini, $\mathrm{SA}_{1.0}$ ara (orta-uzun) periyot ivme değerini temsil etmektedir. $\mathrm{T}_{0}$ değeri ise $\mathrm{T}_{\mathrm{S}}$ değerinin \%20' si olarak dikkate alınmaktadır (Denklem 1.b).

$$
\begin{aligned}
& T_{S}=S A_{1.0} / S A_{0.2} \\
& T_{0}=0.2 T_{S}
\end{aligned}
$$


$\mathrm{Bu}$ yöntemle hesaplanan ivme platosu köşe periyotları kullanılarak elde edilen zarf eğrileri ve proje kapsamında dikkate alınan dönüş periyotlarına $\left(T_{R}=72\right.$ yıl, 475 yıl ve 2475 yıl $)$ ve zemin türlerine (kaya, sert, yumuşak ve çok yumuşak zemin) göre hesaplanan eşit tehlike ivme spektrumları karşılaştırıldığında yöntemin oldukça tutarlı sonuçlar verdiği görülmüsştür. Zarf eğrileri oluşturulurken $\mathrm{T}=0 \mathrm{~s}$ ' deki (PGA) ivme değeri $\mathrm{SA}_{0.2}$ 'nin $\% 40$ ' 1 olarak dikkate alınmıştır (Denklem 2). Bu kabul birçok yönetmelik tarafından kabul edildiği gibi bu çalışmada elde edilen eşit tehlike spektrumlarının PGA / $\mathrm{SA}_{0.2}$ oranları da incelendiğinde ortalamada iyi bir oran olduğu söylenebilmektedir. $T_{S}$ periyodundan daha büyük periyotlar için tasarım ivme spekturumu değerleri de Denklem 2' de verilen bağıntılarla hesaplanabilmektedir.

$$
\begin{array}{ll}
S A=S A_{0.2}\left(0.4+0.6 T / T_{0}\right) & ; T<T_{0} \\
S A=S A_{0.2} & ; T_{0} \leq T \leq T_{S} \\
S A=S A_{0.2} T_{S} / T & ; T_{S}<T \leq T_{L} \\
S A=S A_{0.2} T_{S} T_{L} / T^{2} & ; T>T_{L}
\end{array}
$$

Şekil $6 \mathrm{~V}_{\mathrm{S} 30}=760 \mathrm{~m} / \mathrm{s}$ (kaya zemin) ve $\mathrm{V}_{\mathrm{S} 30}=255 \mathrm{~m} / \mathrm{s}$ (yumuşak zemin) için elde edilmiş 475 yıl dönüş periyoduna karşılık gelen eşit tehlike ivme spektrumları ile bunlara oturtulmuş zarf eğrisi (tasarım) spektrumlarının proje çalışma bölgesinde seçilen bir saha için karşılaştırmalarını göstermektedir. Bu şekilde eşit tehlike spektrumları noktasal, zarf eğrisi spektrumları ise düz çizgilerle gösterilmiştir. Kaya ve yumuşak zemin ise farklı renklerle temsil edilmiştir. Denklem 1 ve 2' ye göre hesaplanan tasarım spektrumunun eşit tehlike spektrumunu uygun bir şekilde temsil ettiği açıkça görülmektedir. Buna ek

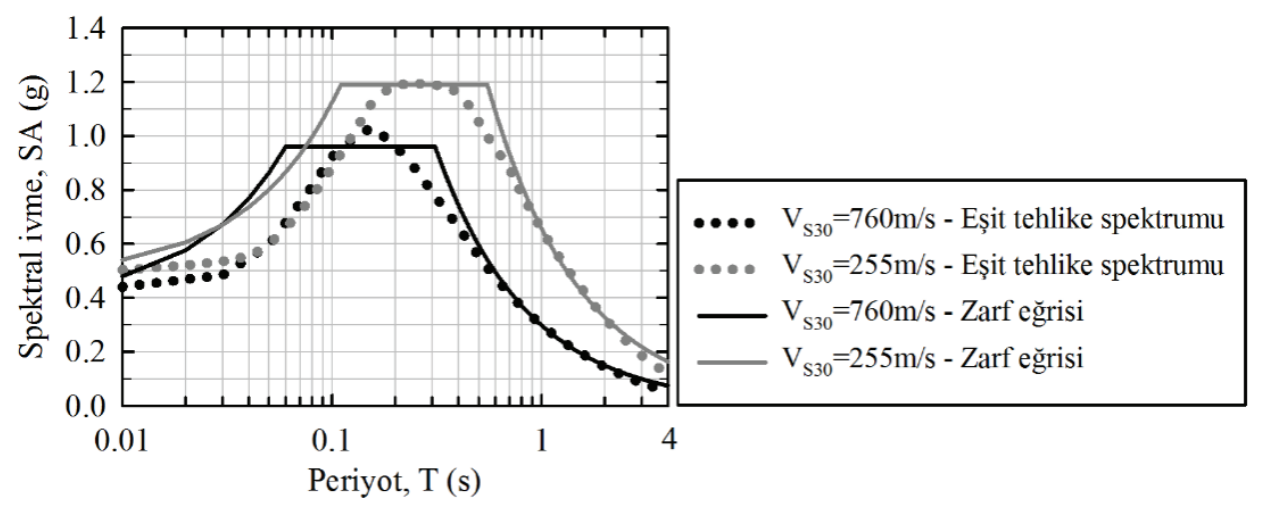

Şekil 6. Kaya $\left(V_{S 30}=760 \mathrm{~m} / \mathrm{s}\right)$ ve Yumuşak $\left(V_{S 30}=255 \mathrm{~m} / \mathrm{s}\right)$ Zemin için $475 \mathrm{Yll}$ Dönüş Periyodu Seviyesinde Eşit Tehlike Spektrumu ile Zarf Ĕgrisi Spektrumu Kıyaslaması 
Tasarım Spektrumu Parametreleri için Olasılıksal Sismik Tehlike Analizlerine ...

olarak zeminin yumuşamasına (veya $\mathrm{V}_{\mathrm{S} 30}$ değerinin düşmesine) bağlı olarak da sabit ivme platosunun genişliğinin ve genliğinin arttı̆ğ da gözlemlenmektedir. Çalışma bölgesinde seçilen bu saha için elde edilen gözlemlere benzer bulgular diğer bütün sahalar için de benzer şekildedir. $\mathrm{Bu}$ bağlamda, bu proje kapsamında $\mathrm{SA}_{0.2}$ ve $\mathrm{SA}_{1.0}$ değerlerinin mevcut olduğu durumlarda tasarım spektrumu ivme platosu köşe periyotlarının Denklem 1' de verilen bağıntılara göre belirlenerek kullanılabileceği sonucu çıkarılmıştır. $\mathrm{SA}_{0.2}$ ve $\mathrm{SA}_{1.0}$ değerlerinin mevcut olmadığ 1 durumlarda ise $T_{S}$ değerinin kaya zemin PGA $\left(\mathrm{PGA}_{R}\right)$ değerine bağlı olarak elde edilebileceği ampirik bağıntılar türetilmiştir. Bu durumda $T_{0}$ değerinin hesaplanabilmesi için yine Denklem 1.b kullanılabilecektir.

$\mathrm{PGA}_{\mathrm{R}}-\mathrm{T}_{\mathrm{S}}$ ampirik bağıntılarının türetilmesinde öncelikli olarak her bir saha için Denklem 1.a' ya göre $T_{S}$ değerleri hesaplanmıştır. Bu değerler projede göz önüne alınan 3 farklı dönüş periyodu ve 4 farklı zemin için ayrı ayrı belirlenmiştir. Sonrasında $T_{S}$ değerlerinin $\mathrm{PGA}_{R}$ ile ilişkilerinin araştırılması amacıyla farklı dönüş periyotları farklı alt şekillerde ve farklı zemin sinıfları da farklı sembol ve renk skalalarında temsil edilerek $P_{G A}$ değerlerine karşılık $T_{S}$ değerlerinin dağ 1 lımları Şekil 7 ' de gösterilmiş̧ir. Buradaki dağılımlara ampirik denklemler uydurulduğunda birçok istatistiksel model içinden Weibull model bütün durumlarda en iyi sonucu vermiştir [düşük standart sapma $(\sigma)$ ve yüksek belirsizlik katsayısı $\left(\mathrm{R}^{2}\right)$ ]. $\mathrm{PGA}_{\mathrm{R}}$ ile $\mathrm{T}_{\mathrm{S}}$ değerleri arasındaki ampirik bağıntının genel formu Denklem 3' de verilmiş̧ir. Farklı dönüş periyotları ve farklı zemin türleri için $T_{S}$ değerlerinin elde edilebilmesini sağlayan denklem katsayıları ile modelin $\sigma$ ve $\mathrm{R}^{2}$ değerleri Tablo 3' de listelenmiştir. Bu katsayılar kullanılarak $\mathrm{PGA}_{\mathrm{R}}$ değerlerine göre hesaplanan ampirik $T_{S}$ değerlerinin değişimi yine Şekil 7 ' de ilgili dağılımların üzerinde siyah eğrilerle gösterilmiştir.

$$
T_{S}=a-b * \exp \left(-c * P G A_{R}{ }^{d}\right)
$$

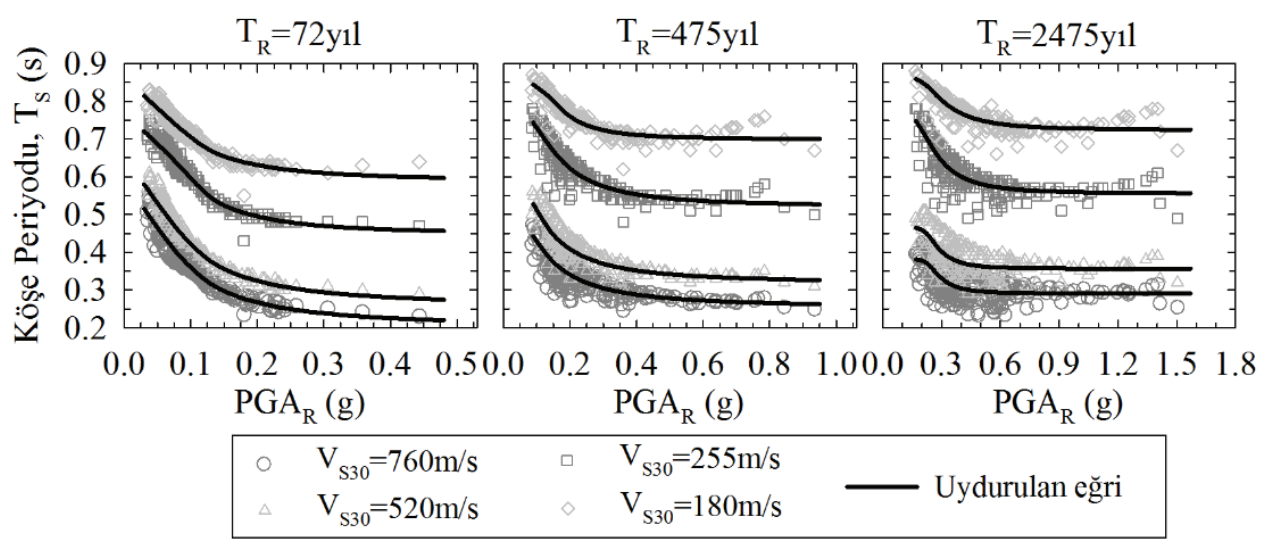

Şekil 7. Farkl Dönüş Periyotları $\left(T_{R}=72\right.$ yll, 475 yll ve 2475 yll) ve Zemin Türleri (Kaya, Sert, Yumuşak ve Çok Yumuşak Zemin) için $P G A_{R}$ Değerlerine Karşıllk Orijinal ve Ampirik $T_{S}$ Değerlerinin Dağıllmları 
Tablo 3. Farklı Zemin Sinıfları ve Dönüş Periyotları için $T_{S}$ Köşe Periyodu Denklem Katsaylları (Denklem 3) ve model Standart Sapması ( $\sigma$ ) ile Belirsizlik Katsayısı $\left(R^{2}\right)$ Değerleri

\begin{tabular}{cccccccc}
\hline Zemin Sınıfi & $\begin{array}{c}\text { Dönüş Periyodu } \\
\left(\mathbf{T}_{\mathbf{R}}, \mathbf{y l}\right)\end{array}$ & $\mathbf{a}$ & $\mathbf{b}$ & $\mathbf{c}$ & $\mathbf{d}$ & $\mathbf{\sigma}$ & $\mathbf{R}^{\mathbf{2}}$ \\
\hline Kaya & 72 & 0.519 & 0.317 & 0.019 & -1.555 & 0.02 & 0.93 \\
$\left(\mathrm{~V}_{\mathrm{S} 30}=760 \mathrm{~m} / \mathrm{s}\right)$ & 475 & 0.498 & 0.246 & 0.039 & -1.516 & 0.03 & 0.77 \\
& 2475 & 0.381 & 0.090 & 0.003 & -4.517 & 0.04 & 0.54 \\
Sert & 72 & 0.583 & 0.327 & 0.018 & -1.574 & 0.02 & 0.95 \\
$\left(\mathrm{~V}_{\mathrm{S} 30}=520 \mathrm{~m} / \mathrm{s}\right)$ & 475 & 0.597 & 0.280 & 0.031 & -1.578 & 0.03 & 0.82 \\
& 2475 & 0.465 & 0.108 & 0.003 & -4.329 & 0.04 & 0.59 \\
& 72 & 0.720 & 0.273 & 0.008 & -1.956 & 0.02 & 0.96 \\
Yumuşak & 475 & 0.764 & 0.245 & 0.026 & -1.879 & 0.03 & 0.82 \\
$\left(\mathrm{~V}_{\mathrm{S} 30}=255 \mathrm{~m} / \mathrm{s}\right)$ & 2475 & 0.760 & 0.205 & 0.019 & -2.808 & 0.04 & 0.66 \\
& 72 & 0.816 & 0.229 & 0.013 & -1.721 & 0.02 & 0.93 \\
Çok Yumuşak & 475 & 0.845 & 0.146 & 0.007 & -2.679 & 0.02 & 0.83 \\
$\left(\mathrm{~V}_{\mathrm{S} 30}=180 \mathrm{~m} / \mathrm{s}\right)$ & 2475 & 0.861 & 0.138 & 0.031 & -2.756 & 0.02 & 0.73 \\
\hline
\end{tabular}
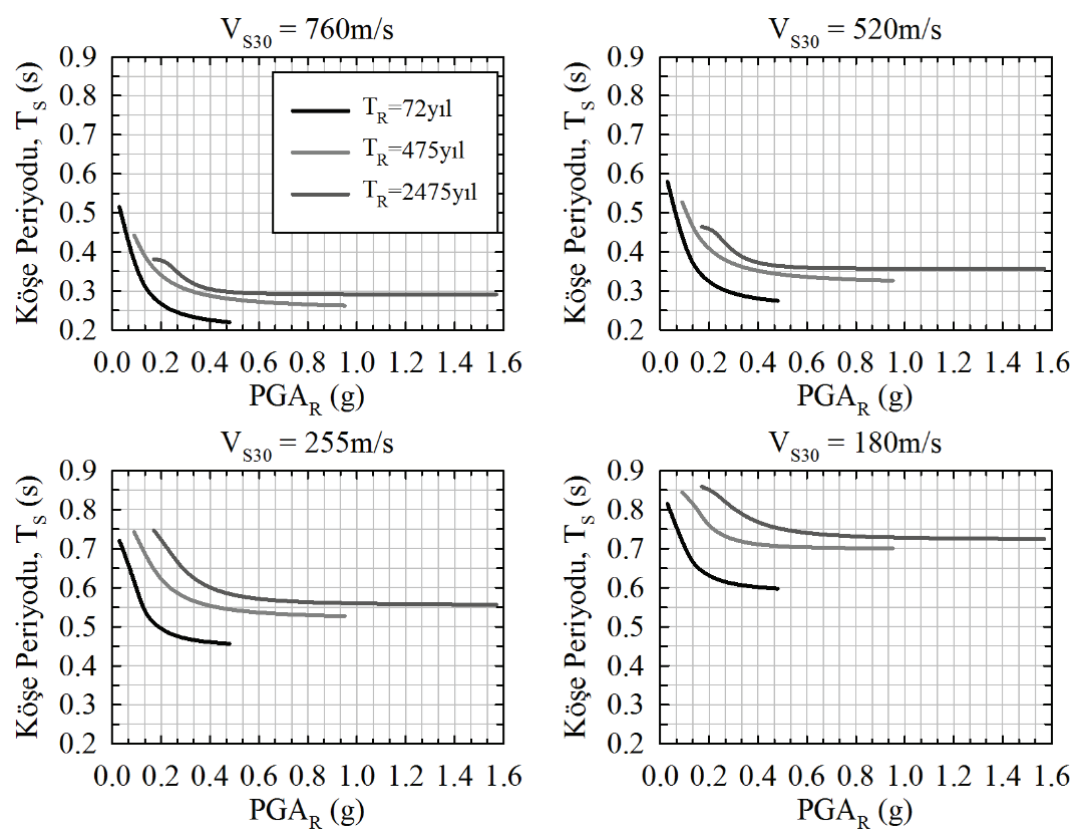

Şekil 8. Farkl Zemin Türleri (Kaya, Sert, Yumuşak ve Çok Yumuşak Zemin) için Farklı Dönüs Periyotlarına ( $T_{R}=72$ yll, 475 yll ve 2475 yll) Göre Ampirik $T_{S}$ Değerlerinin 
Tasarım Spektrumu Parametreleri için Olasılıksal Sismik Tehlike Analizlerine ...

Şekil 7' ye göre yapılan genel gözlemler 1şığında zeminlerin $V_{\mathrm{S} 30}$ değerlerinin düşmesine paralel olarak $T_{S}$ değerlerinin arttı̆̆ görülmektedir. Dikkate alınan bütün dönüşs periyotlarında belirli bir $\mathrm{PGA}_{R}$ değerine kadar $\mathrm{T}_{\mathrm{S}}$ değerlerinde belirli bir düşüş gözlenmekte ve sonrasında ise $T_{S}$ değerleri neredeyse sabit değerlere ulaşmaktadır. Kaya zeminlerde daha düşük $P G A$ değerlerinde sabit $T_{S}$ değerlerine ulaşılırken bu değer daha düşük $V_{S 30}$ değerine sahip yumuşak zeminlere doğru gidildikçe artmaktadır. Benzer irdeleme Şekil 8' de verilen dönüş periyotları karşılaştırmaları cinsinden incelendiğinde ise yüksek dönüş periyotlarında $T_{S}$ değerlerinin sabitlenmesinin daha büyük $\mathrm{PGA}_{R}$ değerlerinde ortaya çıktığı gözlemlenmiştir. Bunlara ek olarak $T_{S}$ köşe periyodunun dikkate alınan dönüş periyodunun artmasına bağlı olarak da arttığı görülmektedir.

\section{ZEMIN FAKTÖRLERININ BELİRLENMESI}

Zemin faktörleri belirlenirken yine olasılıksal sismik tehlike analizi sonucu elde edilen eşit tehlike ivme spektrumları kullanılmıştır. Bu bağlamda yer hareketi mantık ağacı uygulamalarında yer alan YHTD' lerin zemin etkilerini dikkate alma şekilleri oldukça önemlidir. Seçilen YHTD' lerden KAAH15 ve ASB14 ağırlıklı olarak Türk depremlerini içeren bir veri tabanından türetilmiş ve Avrupa ve Orta Doğu için uyumlu olan Sandıkkaya vd. [34] doğrusal olmayan zemin modelini kullanmaktadır. Yine mantık ağacında yer alan CY08 denklemi aktif sığ kabuk içi deprem üreten bölgeler için uygundur ve doğrusal olmayan zemin etkileri spektral tahminlerde dikkate alınmaktadır. Zh06 ise zemin etkilerinin doğrusal olarak modellenerek geliştirilmiş bir denklemdir. Zemin faktörlerinin hesaplanmasında $\mathrm{V}_{\mathrm{S} 30}=760 \mathrm{~m} / \mathrm{s}$ değerine karşlık gelen kaya zemin için elde edilen sonuçlar referans olarak göz önüne alınmıştır. Bir başka deyişle kaya zemin için tasarım spektrumu zemin faktörleri 1.0 olarak önerilmektedir. Zemin faktörleri sert zemin, yumuşak zemin ve çok yumuşak zemin sınıflarını temsil etmek üzere seçilmiş $\mathrm{V}_{\mathrm{S} 30}=520 \mathrm{~m} / \mathrm{s}, 255$ $\mathrm{m} / \mathrm{s}$ ve $180 \mathrm{~m} / \mathrm{s}$ değerleri ve $T_{R}=72$ yll, 475 yıl ve 2475 yıl dönüş periyodu seviyeleri için önerilmiş̧tir. Zemin faktörleri kısa periyot ve orta-uzun periyot bölgesi için iki farklı değer olarak rapor edilmiştir. Burada kısa periyot ivmenin sabit olduğu bölge (yani $\mathrm{SA}_{0.2}$ bölgesi), orta-uzun periyot ise sabit hızı kapsayan bölge (yani $\mathrm{SA}_{1.0}$ bölgesi) olarak dikkate alınmaktadır. Bu bağlamda, zemin faktörleri hesaplanırken Bölüm 3' de belirlenen tasarım spektrumu sabit ivme bölgesi köşe periyotları da $\left(T_{0}\right.$ ve $\left.T_{S}\right)$ dikkate alınmaktadır.

Şekil 9 zemin faktörlerinin hesaplanmasında izlenen yöntemin şematize edilmiş halini göstermektedir. Bu şeklin üst panelinde proje çalışma bölgesinde seçilen bir sahaya ait kaya zemin ve yumuşak zemin için 475 yll dönüş periyoduna karşsıllk elde edilmiş eşit tehlike spektrumları ve yumuşak zemin spektrumuna uydurulan tasarım spektrumu zarf eğrisi gösterilmiştir. Alt panelde ise seçilen her bir periyot değerinde yumuşak zemin için hesaplanan spektral değerlerin kaya zemin için hesaplanan spektral değerlere oranından elde edilen zemin faktörlerinin periyoda göre değişimi gösterilmektedir. Burada kısa periyot bölgesini temsil edecek zemin faktörü $F_{a}$, orta-uzun periyot bölgesini temsil edecek zemin faktörü de $F_{v}$ ile gösterilmiştir. $F_{a}$ değeri ilgili zemin türüne göre belirlenmiş $T_{0}$ ve $T_{S}$ değerleri arası için hesaplanan zemin faktörü değerlerinin ortalaması olarak elde edilirken $\mathrm{F}_{\mathrm{v}}$ değeri de $\mathrm{T}_{\mathrm{S}}$ ile $\mathrm{T}=4.0 \mathrm{~s}$ arası için hesaplanan değerlerin ortalamasıdır.

Yukarıda anlatılan işlemler çalışma bölgesindeki bütün sahalar için 3 farklı zemin türü ve 3 farklı dönüş periyodu için uygulanarak her gruba ait $F_{a} v e F_{v}$ değerleri hesaplanmıştır. Şekil 
10 ' da üst satır $\mathrm{F}_{\mathrm{a}}$ değerlerinin kaya zemin için hesaplanan $\mathrm{SA}_{0.2}\left(\mathrm{SA}_{0.2 \mathrm{R}}\right)$ değerlerine, alt satır ise $\mathrm{F}_{\mathrm{v}}$ değerlerinin yine kaya zemin için hesaplanan $\mathrm{SA}_{1.0}\left(\mathrm{SA}_{1.0 \mathrm{R}}\right)$ değerlerine karşllık gelen zemin türleri ve dönüş periyotları cinsinden dağılımlarını ve bu dağılımlara uydurulan trendleri göstermektedir. $\mathrm{Bu}$ şekillerde zemin türleri farklı sembol ve renk skalalarıyla temsil edilmiştir. Buradaki dağılımlara uydurulan ampirik bağıntılarda yine Weibull modelin iyi sonuç verdiği görülmüştür. $F_{a}$ ve $F_{v}$ değerlerinin belirlenebilmesi için önerilen ampirik bağıntı Denklem 4' de verilmiştir.

$$
F=a-b * \exp \left(-c * I M^{d}\right)
$$

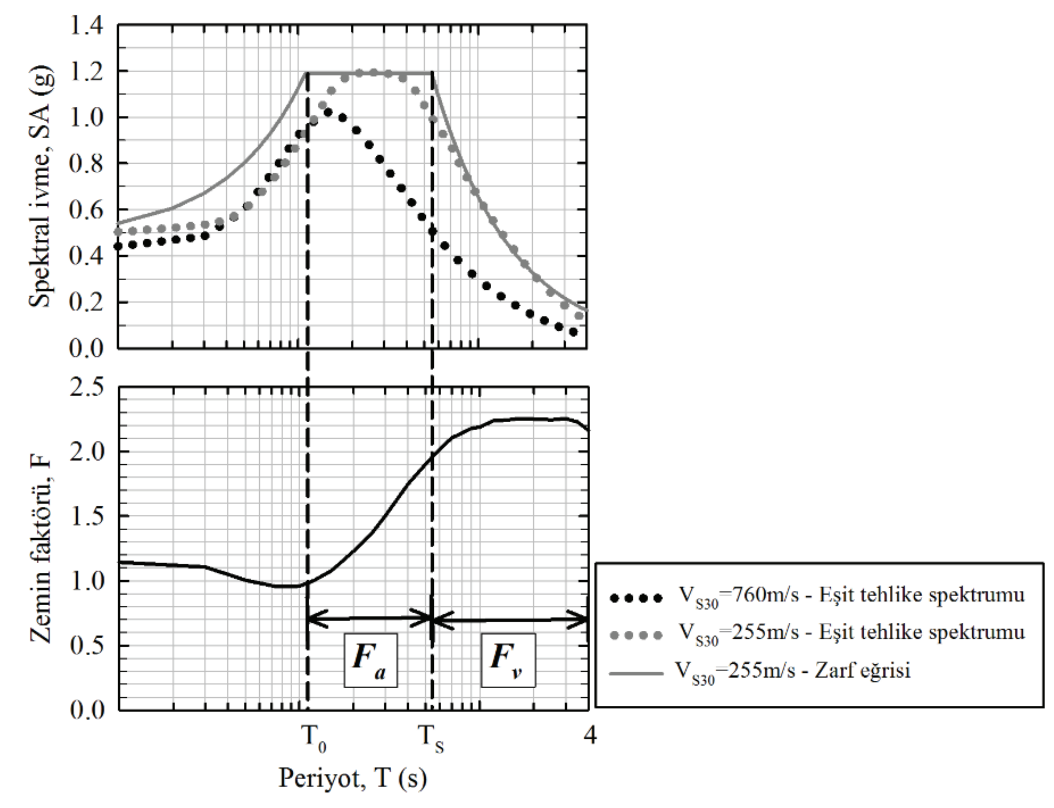

Şekil 9. $F_{a}$ ve $F_{v}$ Değerlerinin Belirlenmesinde İzlenen Yöntem

$\mathrm{Bu}$ denklemde $\mathrm{F}, \mathrm{F}_{\mathrm{a}}$ veya $\mathrm{F}_{\mathrm{v}}$ değerini temsil ederken IM ise kaya zemin için hesaplanan PGA, $\mathrm{SA}_{0.2}$ veya $\mathrm{SA}_{1.0}$ (sırasıyla $\mathrm{PGA}_{\mathrm{R}}, \mathrm{SA}_{0.2 \mathrm{R}}$ ve $\mathrm{SA}_{1.0 \mathrm{R}}$ ) değerlerine karşılık gelmektedir. $\mathrm{a}, \mathrm{b}$, c, ve d denklem katsayıları model $\sigma$ ve $\mathrm{R}^{2}$ değerleri ile birlikte $\mathrm{PGA}_{\mathrm{R}}-\mathrm{F}_{\mathrm{a}}$ durumu için Tablo 4 ve $\mathrm{SA}_{0.2 \mathrm{R}}-\mathrm{F}_{\mathrm{a}}$ ve $\mathrm{SA}_{1.0 \mathrm{R}}-\mathrm{F}_{\mathrm{v}}$ durumları için de Tablo 5' de listelenmiştir. Burada $\mathrm{PGA}_{R}$ ile $\mathrm{F}_{\mathrm{a}}$ zemin faktörü arasında da Şekil 10' un üst satırındaki dağılımlara benzer davranışlar gözlemlenmiştir. $\mathrm{PGA}_{R}-\mathrm{T}_{\mathrm{S}}$ ilişkisi önceki bölümde verildiği için tasarım spektrumu formunun elde edilmesinde $\mathrm{PGA}_{R}-\mathrm{F}_{\mathrm{v}}$ arasındaki ilişkiye gerek yoktur.

$F_{a}$ ve $F_{v}$ değerlerinin genel davranışları dikkate alındığında zeminlerin $V_{S 30}$ değerlerindeki azalmaya bağlı olarak zemin faktörlerinin değerinin arttığı gözlemlenmiştir. Düşük PGA ve spektral ivme değerlerinden yüksek değerlere doğru gidildikçe zemin faktörlerinde hızlıdan 
Tasarım Spektrumu Parametreleri için Olasılıksal Sismik Tehlike Analizlerine ...

yavaşa doğru trend izleyen bir azalım elde edilmiş̧ir. Düşük spektral ordinatlarda $V_{\mathrm{S} 30}$ değerinin düşmesine bağlı olarak zemin faktörlerinde daha hızlı bir artış söz konusudur. Spektral ordinatların artan değerlerine göre katsayılardaki düşüşün en yavaş gözlemlendiği durum sert zemin türünde ortaya çıkmaktadır. $F_{v}$ değerleri $F_{a}$ değerlerine göre uzun periyotlardaki zemin büyütmesinin daha belirgin olması beklentisine paralel olarak daha büyük değerler vermiştir. $F_{v}$ değerlerinde $V_{S 30}$ değişiminin etkisi $F_{a}$ değerlerindeki $V_{S 30}$ değişiminin etkisine göre çok daha belirgindir. $F_{a}$ değerlerinde gözlemlenen belirli bir spektral genliğe ulaşıldığında ortaya çıkan yakınsama (yani zemin türünün zemin faktörleri üzerinde etkisinin azalması) $F_{v}$ dağılımlarında hiçbir şekilde ortaya çıkmamıştır. Sahaların dönüş periyotlarındaki değişim incelediğinde (Şekil 11) düşük dönüş periyotlarında $F_{a} v e$ $\mathrm{F}_{\mathrm{v}}$ katsayılarının yüksek dönüş periyotlarına göre daha hızlı düştüğü gözlemlenmiştir. $\mathrm{Bu}$ gözleme ek olarak bütün durumlar için yapılan karşılaştırmalar zemin faktörlerinin dikkate alınan dönüş periyodunun artmasına bağlı olarak arttığını göstermektedir. Bu artış düşük $\mathrm{V}_{\mathrm{S} 30}$ değerine sahip zemin türlerinde daha etkili olurken sert zeminlerde daha yavaştır.
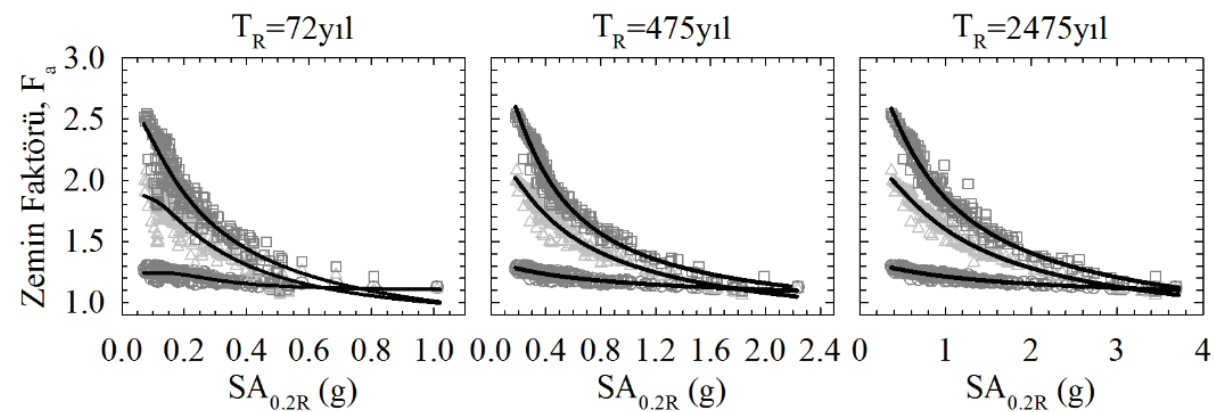

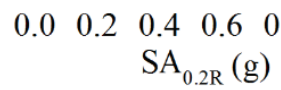
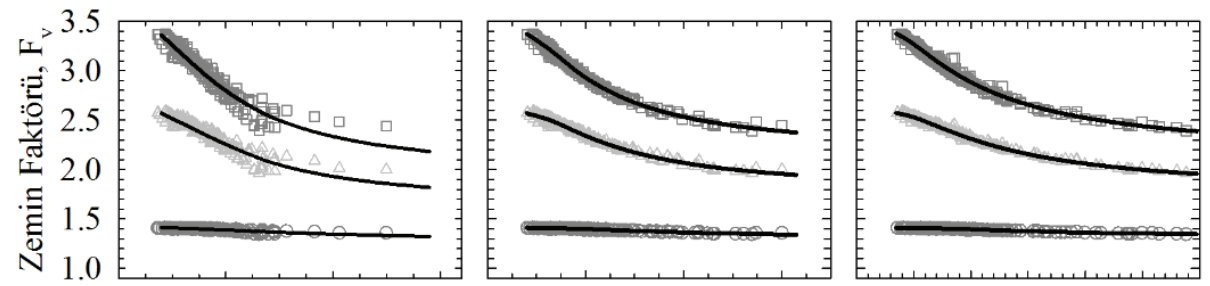

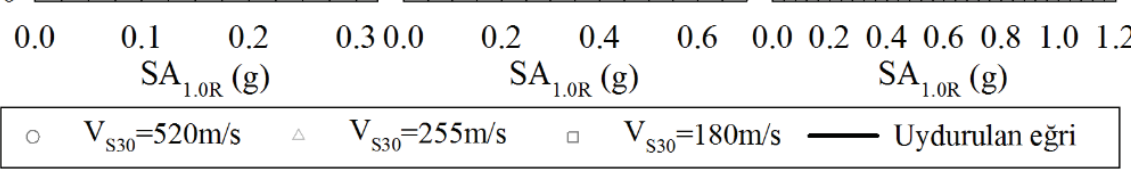

Şekil 10. Farklı Dönüş Periyotları $\left(T_{R}=72\right.$ yll, 475 yll ve 2475 yll) ve Zemin Türleri (Sert, Yumuşak ve Çok Yumuşak Zemin) için Spektral İvme Değerlerine Karşıllk Orijinal ve Ampirik $F_{a}$ ve $F_{v}$ Değerlerinin Dağgllmları 

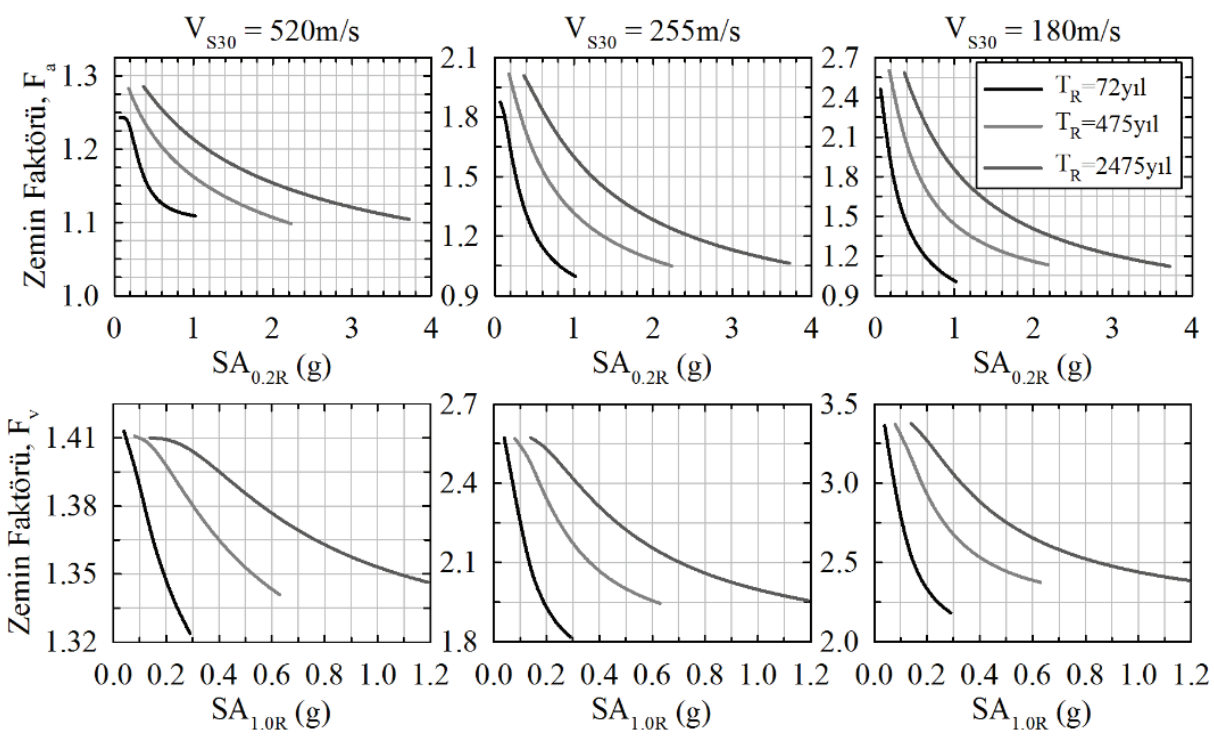

Şekil 11. Farklı Zemin Türleri (Kaya, Sert, Yumuşak ve Çok Yumuşak Zemin) için Farklı Dönüş Periyotlarına ( $T_{R}=72$ yll, 475 yll ve 2475 yll) Göre Ampirik $F_{a}$ ve $F_{v}$ Değerlerinin Karşılaştırılması

Tablo 4. Farklı Zemin Sinıfları ve Dönüş Periyotları için $P G A_{R}$ Değerine Göre $F_{a}$ Denklem Katsayllarl ve Modelin $\sigma$ ile $R^{2}$ Değerleri

\begin{tabular}{|c|c|c|c|c|c|c|c|}
\hline \multirow{2}{*}{$\begin{array}{c}\text { Zemin } \\
\text { Sinıfi }\end{array}$} & \multirow{2}{*}{$\begin{array}{c}T_{R} \\
(y 1)\end{array}$} & \multicolumn{6}{|c|}{$\mathbf{F a}$} \\
\hline & & $\mathbf{a}$ & b & c & d & $\sigma$ & $\mathbf{R}^{2}$ \\
\hline Kaya & 72 & 1 & 0 & 0 & 0 & - & - \\
\hline $\mathrm{V}_{\mathrm{S} 30}$ & 475 & 1 & 0 & 0 & 0 & - & - \\
\hline $760 \mathrm{~m} / \mathrm{s}$ & 2475 & 1 & 0 & 0 & 0 & - & - \\
\hline Sert & 72 & 1.252 & 0.243 & 0.141 & -1.143 & 0.03 & 0.67 \\
\hline $\mathrm{V}_{\mathrm{S} 30}$ & 475 & 1.326 & 0.449 & 0.656 & -0.515 & 0.02 & 0.82 \\
\hline $520 \mathrm{~m} / \mathrm{s}$ & 2475 & 1.321 & 0.369 & 0.699 & -0.677 & 0.02 & 0.88 \\
\hline Yumuşak & 72 & 1.890 & 1.136 & 0.090 & -1.188 & 0.10 & 0.82 \\
\hline $\mathrm{V}_{\mathrm{S} 30}$ & 475 & 2.144 & 1.454 & 0.269 & -0.889 & 0.06 & 0.94 \\
\hline $255 \mathrm{~m} / \mathrm{s}$ & 2475 & 2.128 & 1.454 & 0.458 & -0.950 & 0.05 & 0.96 \\
\hline Çok Yum. & 72 & 2.604 & 2.057 & 0.119 & -0.925 & 0.13 & 0.87 \\
\hline $\mathrm{V}_{\mathrm{S} 30}$ & 475 & 2.825 & 1.986 & 0.146 & -1.085 & 0.06 & 0.97 \\
\hline $180 \mathrm{~m} / \mathrm{s}$ & 2475 & 2.968 & 2.321 & 0.336 & -0.940 & 0.07 & 0.96 \\
\hline
\end{tabular}


Tasarım Spektrumu Parametreleri için Olasılıksal Sismik Tehlike Analizlerine ...

Tablo 5. Farklı Zemin Sinufları ve Dönüş Periyotlart için $S A_{0.2 R}$ Değerine Göre $F_{a}$ ve $S A_{1.0 R}$ Değerine Göre $F_{v}$ Denklem Katsayılart ve Modelin $\sigma$ ile $R^{2}$ Değerleri

\begin{tabular}{|c|c|c|c|c|c|c|c|}
\hline \multirow{2}{*}{$\begin{array}{l}\text { Zemin } \\
\text { Sinıfı }\end{array}$} & \multirow{2}{*}{$\begin{array}{c}T_{R} \\
(y 1)\end{array}$} & \multicolumn{6}{|c|}{$\mathbf{F a}$} \\
\hline & & $\mathbf{a}$ & b & c & d & $\sigma$ & $\mathbf{R}^{2}$ \\
\hline Kaya & 72 & 1 & 0 & 0 & 0 & - & - \\
\hline $\mathrm{V}_{\mathrm{S} 30}$ & 475 & 1 & 0 & 0 & 0 & - & - \\
\hline $760 \mathrm{~m} / \mathrm{s}$ & 2475 & 1 & 0 & 0 & 0 & - & - \\
\hline Sert & 72 & 1.243 & 0.143 & 0.063 & -2.227 & 0.03 & 0.67 \\
\hline $\mathrm{V}_{\mathrm{S} 30}$ & 475 & 1.330 & 0.468 & 1.027 & -0.472 & 0.02 & 0.81 \\
\hline $520 \mathrm{~m} / \mathrm{s}$ & 2475 & 1.324 & 0.379 & 1.233 & -0.623 & 0.02 & 0.88 \\
\hline Yumuşak & 72 & 1.880 & 1.085 & 0.210 & -1.217 & 0.10 & 0.81 \\
\hline $\mathrm{V}_{\mathrm{S} 30}$ & 475 & 2.161 & 1.485 & 0.565 & -0.831 & 0.06 & 0.94 \\
\hline $255 \mathrm{~m} / \mathrm{s}$ & 2475 & 2.129 & 1.442 & 1.004 & -0.913 & 0.05 & 0.96 \\
\hline Çok Yum. & 72 & 2.575 & 1.974 & 0.234 & -0.941 & 0.13 & 0.86 \\
\hline $\mathrm{V}_{\mathrm{S} 30}$ & 475 & 2.865 & 2.037 & 0.359 & -1.016 & 0.07 & 0.97 \\
\hline $180 \mathrm{~m} / \mathrm{s}$ & 2475 & 2.963 & 2.291 & 0.727 & -0.914 & 0.07 & 0.97 \\
\hline
\end{tabular}

\begin{tabular}{|c|c|c|c|c|c|c|c|}
\hline \multirow{2}{*}{$\begin{array}{c}\text { Zemin } \\
\text { Sinıfı }\end{array}$} & \multirow{2}{*}{$\begin{array}{c}T_{R} \\
(y l l)\end{array}$} & \multicolumn{6}{|c|}{$\mathbf{F v}$} \\
\hline & & a & b & c & d & $\sigma$ & $\mathbf{R}^{2}$ \\
\hline Kaya & 72 & 1 & 0 & 0 & 0 & - & - \\
\hline $\mathrm{V}_{\mathrm{S} 30}$ & 475 & 1 & 0 & 0 & 0 & - & - \\
\hline $760 \mathrm{~m} / \mathrm{s}$ & 2475 & 1 & 0 & 0 & 0 & - & - \\
\hline Sert & 72 & 1.415 & 0.181 & 0.210 & -0.959 & 0.01 & 0.76 \\
\hline $\mathrm{V}_{\mathrm{S} 30}$ & 475 & 1.411 & 0.132 & 0.375 & -1.129 & 0.01 & 0.93 \\
\hline $520 \mathrm{~m} / \mathrm{s}$ & 2475 & 1.410 & 0.096 & 0.522 & -1.390 & 0.01 & 0.96 \\
\hline Yumuşak & 72 & 2.587 & 0.948 & 0.033 & -1.501 & 0.05 & 0.91 \\
\hline $\mathrm{V}_{\mathrm{S} 30}$ & 475 & 2.577 & 0.795 & 0.118 & -1.450 & 0.02 & 0.99 \\
\hline $255 \mathrm{~m} / \mathrm{s}$ & 2475 & 2.584 & 0.818 & 0.335 & -1.301 & 0.01 & 0.99 \\
\hline Çok Yum. & 72 & 3.414 & 1.472 & 0.029 & -1.481 & 0.06 & 0.93 \\
\hline $\mathrm{V}_{\mathrm{S} 30}$ & 475 & 3.402 & 1.224 & 0.089 & -1.478 & 0.02 & 0.99 \\
\hline $180 \mathrm{~m} / \mathrm{s}$ & 2475 & 3.418 & 1.271 & 0.263 & -1.305 & 0.03 & 0.99 \\
\hline
\end{tabular}




\section{5. ÖNERILEN TASARIM SPEKTRUMU VE MEVCUT YÖNETMELİK TASARIM SPEKTRUMLARI İLE YAPILAN KARŞILAŞTIRMALAR}

\section{1. Önerilen Tasarım Spektrumunun Değerlendirilmesi}

$\mathrm{Bu}$ çalışma kapsamında olasılıksal sismik tehlike analizleri sonuçlarına bağlı olarak önerilen tasarım spektrumunun sadece kaya zemin için hesaplanan PGA $\left(\mathrm{PGA}_{R}\right)$ değerinin mevcut olduğu durumlarda elde edilebilmesi için öncelikle Denklem 5 kullanılarak zemin sınıfına göre değiştirilmiş kısa periyot spektral ivme değerinin $\left(\mathrm{SA}_{\mathrm{DS}}\right)$ hesaplanması gerekmektedir. Sonrasında Denklem 2' de $\mathrm{SA}_{0.2}$ değeri yerine $\mathrm{SA}_{\mathrm{DS}}$ kullanılarak tasarım spektrumu elde edilebilmektedir. Burada $F_{a}$ Denklem 4' e göre Tablo 4' de verilen katsayılar kullanılarak hesaplanırken $T_{S}$ değeri Denklem 3 ve Tablo 3 kullanılarak elde edilebilmektedir. $\mathrm{T}_{0}$ değeri yine Denklem 1.b' de verildiği gibi $\mathrm{T}_{\mathrm{S}}$ değerinin $\% 20$ ' si olarak dikkate alınmalıdır. $T_{L}$ değeri ise bu çalışmada dikkate alınan bölge için Akkar ve Kale [35] çalışmasına göre seçilebilmektedir.

$$
S A_{D S}=2.5 F_{a} P G A_{R}
$$

$\mathrm{Bu}$ çalı̧̧ma için dikkate alınan bölgeden rasgele seçilmiş bir saha için orijinal kaya zemin eşit tehlike spektrumu (475 yıl dönüş periyodu) ile yukarıdaki denklemler kullanılarak elde edilen tasarım spektrumunun karşılaştırılması Şekil 12.a' da gösterilmiş̧ir. Bu sahanın konumu gözetilerek ve Akkar ve Kale [35] çalışması dikkate alınarak tasarım spektrumunda $T_{L}$ değeri $3 \mathrm{~s}$ olarak hesaba katılmıştır. Şekil 12.a' da verilen olasılıksal sismik tehlike analizinden elde edilen (orijinal) ivme spektrumu ile bu çalışmada verilen katsayılara göre çıkarılan tasarım spektrumunun (önerilen) karşılaştırmasının birbiriyle oldukça tutarlı sonuç verdiği görülmektedir.

$\mathrm{Bu}$ çalışmada tasarım spektrumunun kaya zemin için hesaplanan $\mathrm{T}=0.2 \mathrm{~s}$ ve $\mathrm{T}=1.0 \mathrm{~s}$ ivme değerlerinin (sırasiyla $\mathrm{SA}_{0.2 \mathrm{R}}$ ve $\mathrm{SA}_{1.0 \mathrm{R}}$ ) mevcut olduğu durumlarda elde edilmesinin ilk aşamasında ise Denklem 6 kullanılmaktadır. $\mathrm{Bu}$ denklemde $\mathrm{SA}_{\mathrm{DS}}$ parametresi kısa periyot bölgesi ve $\mathrm{SA}_{D 1}$ parametresi de orta-uzun periyot bölgesi için tasarım spektral ivme değerini göstermektedir. $F_{a}$ ve $F_{v}$ Denklem 4' e göre Tablo 5' de verilen katsayılar kullanılarak hesaplanabilmektedir. $\mathrm{T}_{0}$ ve $\mathrm{T}_{\mathrm{S}}$ köşe periyotlarının hesabı ise Denklem 1' de $\mathrm{SA}_{0.2}$ ve $\mathrm{SA}_{1.0}$ değerleri sırasıyla $\mathrm{SA}_{\mathrm{DS}}$ ve $\mathrm{S} \mathrm{A}_{\mathrm{D} 1}$ değerleri ile değiştirilerek yapılmalıdır. Son aşamada ise PGA için izlenen yönteme benzer şekilde Denklem 2' de $\mathrm{SA}_{0.2}$ değeri yerine $\mathrm{SA}_{\mathrm{DS}}$ kullanılarak nihai tasarım spektrumu elde edilebilmektedir.

$$
S A_{D S}=F_{a} S A_{0.2 R}
$$

$$
S A_{D I}=F_{v} S A_{1.0 R}
$$

Proje çalışma bölgesinden rasgele seçilmiş bir saha için orijinal yumuşak zemin eşit tehlike spektrumu (475 yıl dönüş periyodu) ile bu çalışmada önerilen denklemler kullanılarak elde edilen tasarım spektrumunun karşılaş̧ııılması Şekil 12.b' de gösterilmiştir. Bu sahanın $T_{L}$ değeri yine Akkar ve Kale [35] çalışması dikkate alınarak tasarım spektrumunda $5 \mathrm{~s}$ olarak 
Tasarım Spektrumu Parametreleri için Olasılıksal Sismik Tehlike Analizlerine ...

dikkate alınmıştır (Not: TBDY [10]' da $T_{L}$ değerlerinin $6 \mathrm{~s}$ olarak dikkate alınması önerilmektedir). Orijinal spektrum değerleri $\mathrm{T}=4.0 \mathrm{~s}$ ' ye kadar elde edilebildiği için tasarım spektrumu da $\mathrm{T}=4 \mathrm{~s}$ ' ye kadar çıkarılmışıtır. Burada yapılan kıyaslama yine çalışmada önerilen değerlerin tutarlı sonuçlar verdiğini göstermektedir.
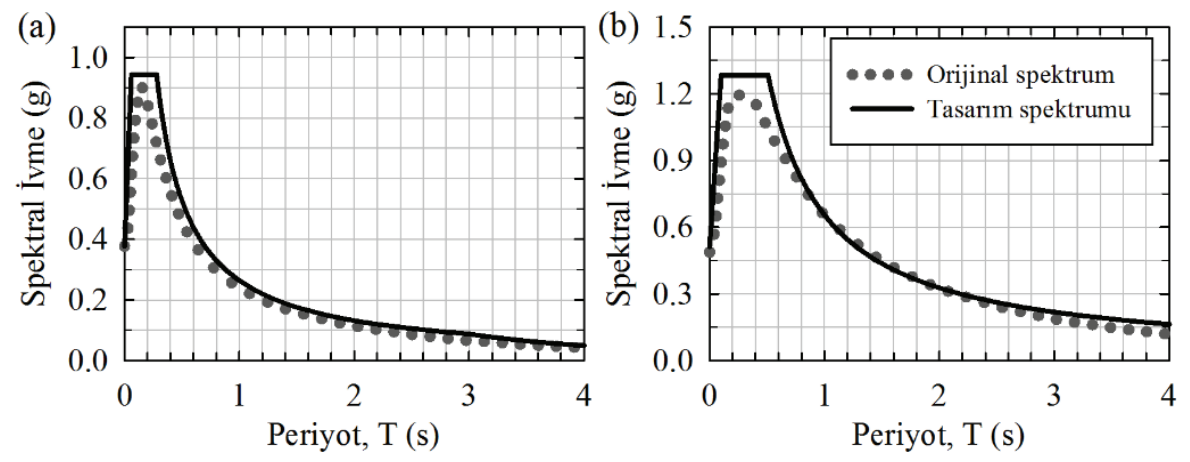

Şekil 12. Orijinal Spektrum ile Önerilen Tasarım Spektrumunun Karşılaştırılması: a) $P G A_{R}$ ' ye Băgll, b) $S A_{0.2 R}$ ve $S A_{1.0 R}$ ' ye Bă̆gl

\subsection{TDY07, EC08 ve NEHRP Tasarım Spektrumları ile Yapılan Karşılaştırmalar}

Bu bölümde, çalışmada önerilen tasarım spektrumu ile mevcut TDY07, EC8 ve NEHRP tasarım spektrumları arasında iki farklı sismik aktivite seviyesi (yüksek ve orta derece) ve dört farklı zemin türü için yapılan karşılaştırmalar verilmiş̧ir. Yüksek sismik aktivite seviyesi için $\mathrm{PGA}_{\mathrm{R}}=0.4 \mathrm{~g}, \mathrm{SA}_{0.2 \mathrm{R}}=1.0 \mathrm{~g}$ ve $\mathrm{SA}_{1.0 \mathrm{R}}=0.3 \mathrm{~g}$ seçilirken orta sismik aktive seviyesi ise $\mathrm{PGA}_{\mathrm{R}}=0.2 \mathrm{~g}, \mathrm{SA}_{0.2 \mathrm{R}}=0.5 \mathrm{~g}$ ve $\mathrm{SA}_{1.0 \mathrm{R}}=0.2 \mathrm{~g}$ değerleri ile temsil edilmiştir. Seçilen zemin türleri ise kaya, sert, yumuşak ve çok yumuşak zemin olarak göz önüne alınmıştır. Bu çalışma ve NEHRP tasarım spektrumunda değişken olarak tanımlanan $T_{L}$ değeri yüksek sismik aktivite seviyesinde $T_{L}=8 \mathrm{~s}$ kabul edilirken orta sismik aktivite seviyesi için $T_{L}=3$ s olarak dikkate alınmıştır. TDY07' de Z1, Z2, Z3 ve Z4 olarak tanımlanan zemin sınıfları karşılaştırmalarda sırasıyla kaya, sert, yumuşak ve çok yumuşak zemin olarak kabul edilmiştir. NEHRP' de tanımlanan zemin sınıflardırmasına göre kaya zemin olarak B sınıfi $\left(760 \mathrm{~m} / \mathrm{s} \leq \mathrm{V}_{\mathrm{S} 30}<1500 \mathrm{~m} / \mathrm{s}\right)$ göz önüne alınmıştır. Burada yapılan karşılaştırmalarda NEHRP' den elde edilen değerler Türkiye Bina Deprem Yönetmeliği taslağından (TBDY [10]) elde edilecek değerlere eşdeğerdir.

Şekil 13.a ve b sırasıyla yüksek ve orta sismik aktivite seviyeleri için farklı zemin türleri gözetilerek yapılan karşılaştırmaları göstermektedir. Bu çalışmada önerilen ve TDY07, EC8 ve NEHRP' de tanımlanan tasarım spektrumları bu şekillerde farklı renk tonları ile temsil edilmiştir. Bu çalışmada önerilen tasarım spektrumu, kaya ve sert zemin türlerinde diğer tasarım spektrumları ile benzer davranışlar gösterirken yumuşak ve çok yumuşak zemin grupları için özellikle de kısa periyot bölgesinde diğerlerine göre daha yüksek değerler almıştır. Orta sismik aktivite seviyesi için de benzer gözlemler yapmak mümkündür fakat yumuşak ve çok yumuşak zemin türlerinde bu çalışma NEHRP ile yakın sonuçlar verirken TDY07 ve EC8 değerleri bu ikisinin oldukça altında değerler vermiştir. TDY07' de tanımlanan tasarım spektrumunda zeminin yumuşamasına bağlı olarak kısa periyot 
bölgesindeki (ivme platosu) spektral değerlerde herhangi bir değişim uygulanmamasına bağlı olarak sert zeminden yumuşak zemin türlerine doğru gidildikçe diğer tasarım spektrumlarına göre genelde daha düşük değerler gözlemlenmektedir. EC8' de bu değişimin uygulanmasına karşın doğrusal olmayan zemin etkilerinin dikkate alınmıyor olması bu sonucu ortaya çıkarmaktadır. TDY07 tasarım spektrumu gerek bu çalışmada tanımlanan tasarım spektrumu gerekse EC8 ve NEHRP tasarım spektrumlarına göre uzun periyoda doğru gidildikçe aşırı güvenli sonuçlar vermeye başlamaktadır. Bu etki spektral yer değiştirmeler cinsinden düşünülecek olursa arada oluşacak farklar çok daha ciddi boyutlara ulaşmaktadır. Kaya zemin için yapılan karşılaş̧ırmalarda NEHRP kısa periyot değerinin diğerlerinin altında olma sebebi burada önerilen katsayıların kaya zemin sınıfına (yani $760 \mathrm{~m} / \mathrm{s} \leq \mathrm{V}_{\mathrm{S} 30}<1500 \mathrm{~m} / \mathrm{s}$ ) karşıllı gelmesidir. Yani referans kaya olan $\mathrm{V}_{\mathrm{S} 30}=760$ $\mathrm{m} / \mathrm{s}^{\prime}$ den daha yüksek bir $\mathrm{V}_{\mathrm{S} 30}$ değeri ile kaya sınıfı temsil edildiği için referans değere bir azaltma uygulanmaktadır. $\mathrm{Bu}$ çalı̧̧mada elde edilen sonuçlarla yönetmelik tasarım spektrumları arasında genel bir değerlendirme yapıldığında bu çalışma ile NEHRP (dolayısıyla da TBDY [10]) tutarlı sonuçlar vermektedir. Özellikle de orta sismik aktivite seviyesinde mevcut TDY07 ve EC8 tasarım spektrumlarının doğrusal olmayan zemin etkilerini hesaba katmamalarına bağlı olarak güvensiz tarafta kaldıklarını söylemek mümkündür. Yüksek sismik aktivite seviyesinde ise TDY07 ve EC8 uzun periyotlarda bu çalışmada ve NEHRP' de önerilen spektrumlardan daha yüksek değerler almaktadır.

\section{SONUÇLAR VE ÖNERILER}

Bu çalışma kapsamında tasarım spektrumu sabit ivme platosu köşe periyotları $\left(T_{0}\right.$ ve $\left.T_{S}\right)$ ve referans kaya zemine $\left(\mathrm{V}_{\mathrm{S} 30}=760 \mathrm{~m} / \mathrm{s}\right)$ göre zemin faktörleri Türkiye' de Kuzey Anadolu Fay Hattı üzerinde seçilen bir bölge için farklı zemin türleri ve dönüş periyotları dikkate alınarak yapılan sismik tehlike analiz sonuçları kullanılarak belirlenmiştir. Bu çalışmaya benzer yapılan literatürdeki çalışmalarda gerçek yer hareketi ivme kayıtları kullanılarak veya yer hareketi tahmin modellerinin yardımıyla elastik ivme spektrumları hesaplanmış ve bunlar üzerinde işlem yapılarak tasarım spekturumları elde edilmiştir. Bu noktadan hareketle bu makalede yapılan değerlendirmelerde daha farklı ve daha güncel bilimsel verilere dayalı bir çalışma ortaya çıkarılmıştır. Çalışma sonunda $T_{0}, T_{S}$ ve zemin faktörlerinin belirlenebilmesi için iki farklı yaklaşım önerilmiş̧ir. İlk yaklaşım sadece kaya zemin içi elde edilen PGA değerlerinin mevcut olduğu durumlar için geçerlidir. Burada $P A_{R}$ değerine bağlı olarak önerilen ampirik bağıntılar yardımıyla $T_{0}, T_{S}$ ve zemin faktörleri hesaplanarak tasarım spektrumu formu çıkarılmaktadır. İkinci yaklaşımda ise tasarım spektrumu $\mathrm{T}=0.2 \mathrm{~s}$ ve $1.0 \mathrm{~s}$ ' deki kaya zemin spektral ivme değerlerine bağlı olarak elde edilmektedir. $\mathrm{Bu}$ yaklaşımda zemin faktörleri $\mathrm{SA}_{0.2 \mathrm{R}}$ ve $\mathrm{SA}_{1.0 \mathrm{R}}$ spektral ivme değerlerine göre ampirik bağıntılardan belirlendikten sonra zemin etkisi dahil edilmiş spektral değerler $\left(S_{D S}\right.$ ve $S_{D 1}$ ) hesaplanmakta ve bunların oranından da $T_{0}$ ve $T_{S}$ köşe periyotları elde edilmektedir. Son olarak bütün unsurlar birleştirilerek tasarım spektrumu formu oluşturulabilmektedir.

Bu çalışma kapsamında yapılan gözlemler ışığında TDY07' de tanımlanan tasarım spektrumunun güncellenmesinin oldukça yerinde olduğu net bir şekilde ortaya konulmuştur. Tasarım spektrumlarında zemin etkileri, kontrol periyotlarının tanımlanması ve dönüş periyotlarına göre önerilen değerlerin dikkatlice seçilmesi gerektiği aşikardır. Yönetmeliklerde tanımlanan tasarım spektrumlarında ivme platosu köşe periyotlarının 
Tasarım Spektrumu Parametreleri için Olasılıksal Sismik Tehlike Analizlerine ...

sadece zemin türüne göre değişmeyip buna ek olarak spektral genliklerdeki değişimin ve dönüş periyodunun da etkisinin göz ardı edilmemesi önerilmektedir. Tüm bu detaylara ek olarak şu husus unutulmamalıdır ki bu çalışmada elde edilen bulgular Kuzey Anadolu Fay Hattı üzerinde seçilen bir bölge için yapılan sismik tehlike analizlerine dayanmaktadır. Bu noktadan hareketle çalışmanın tüm Türkiye’ yi kapsayacak şekilde genişletilerek yapılması daha güvenilir bilgiler alınmasını da sağlayacaktır.
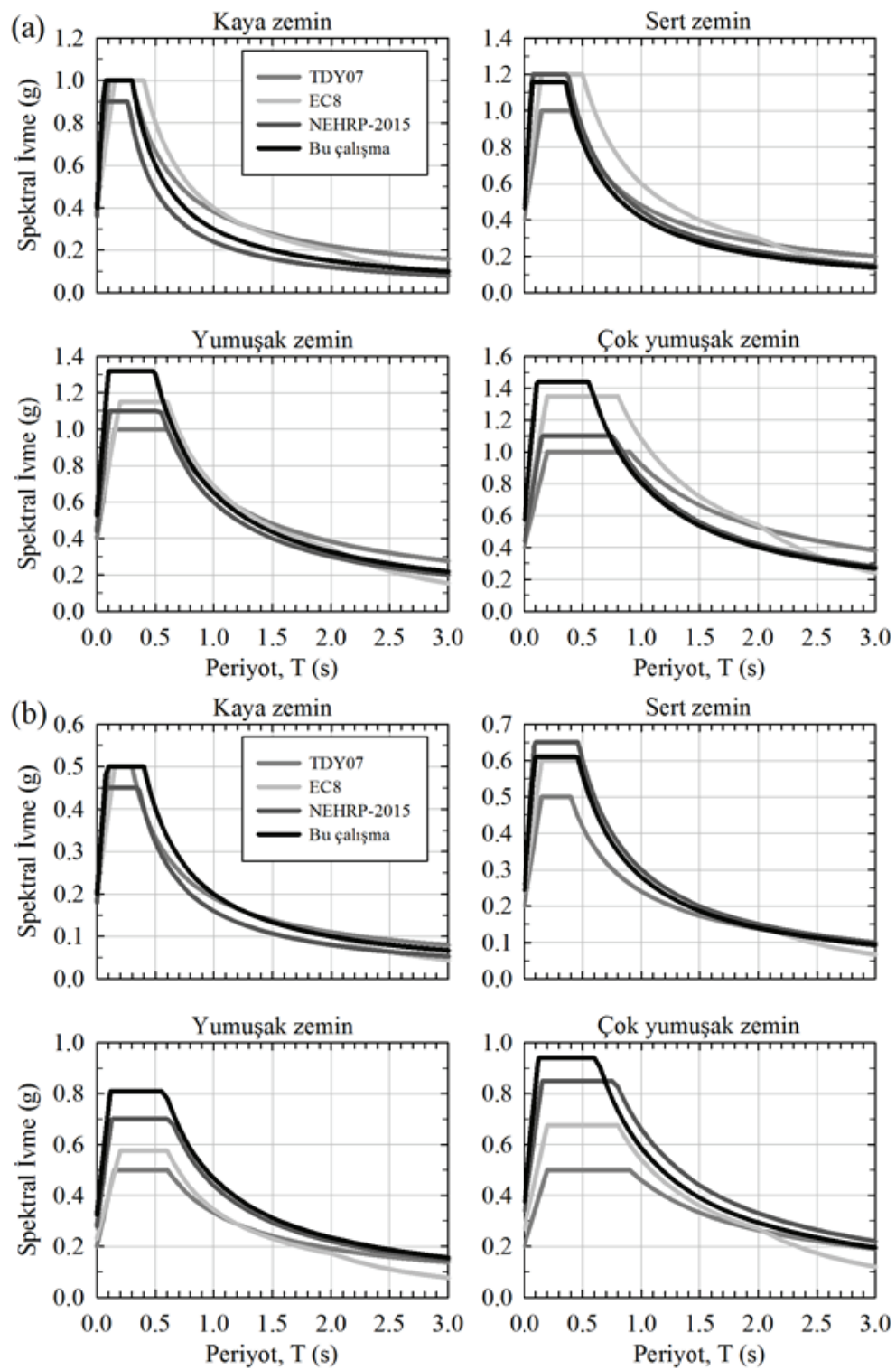

Şekil 13. a) Yüksek ve b) Orta Sismik Aktivite Seviyesi için Yapılan Tasarım Spektrumu Karșılaștırmaları 


\section{Semboller}

\begin{tabular}{|c|c|}
\hline EC8 & Eurocode- 8 \\
\hline EDR & Öklid Uzaklığına Bağlı Sıralama \\
\hline $\mathrm{F}$ & Zemin Faktörü \\
\hline$F_{a}$ & Kısa Periyot Zemin Faktörü \\
\hline $\mathrm{F}_{\mathrm{v}}$ & Orta-Uzun Periyot Zemin Faktörü \\
\hline $\mathrm{IM}$ & Şiddet Ölçütü \\
\hline$\kappa$ & Model Yanl1lı̆̆ 1 \\
\hline LH & Olabilirlik \\
\hline LLH & Logaritmik Olabilirlik \\
\hline MDE & Değiştirilmiş Öklid Uzaklığı \\
\hline M & Mantık Ağacı Uygulaması Sayısı \\
\hline $\mathrm{M}_{\mathrm{w}}$ & Moment Magnitüd \\
\hline $\mathrm{N}$ & Normal Fay \\
\hline $\mathrm{N}_{\text {deprem }}$ & Deprem Sayısı \\
\hline $\mathrm{N}_{\text {kayit }}$ & Kuvvetli Yer Hareketi İvme Kaydı Sayısı \\
\hline NEHRP & National Earthquake Hazards Reduction Program \\
\hline NSE & Nash ve Sutcliffe Etkinlik Katsayısı \\
\hline PGA & Maksimum Yer İvmesi \\
\hline $\mathrm{PGA}_{\mathrm{R}}$ & Kaya Zemin Maksimum Yer İvmesi \\
\hline $\mathrm{R}$ & Ters Fay \\
\hline $\mathrm{R}^{2}$ & Belirsizlik Katsayısı \\
\hline $\mathrm{R}_{\mathrm{JB}}$ & Joyner-Boore Mesafesi \\
\hline $\mathrm{R}_{\max }$ & Maksimum Mesafe \\
\hline $\mathrm{R}_{\mathrm{RUP}}$ & Fay Kırığına En Yakın Mesafe \\
\hline S & Doğrultu Atımlı Fay \\
\hline SA & Spektral İvme \\
\hline $\mathrm{SA}_{0.2}$ & $\mathrm{~T}=0.2 \mathrm{~s}$ Spektral İvmesi \\
\hline $\mathrm{SA}_{0.2 \mathrm{R}}$ & Kaya Zemin $\mathrm{T}=0.2 \mathrm{~s}$ Spektral İvmesi \\
\hline $\mathrm{SA}_{1.0}$ & $\mathrm{~T}=1.0 \mathrm{~s}$ Spektral İvmesi \\
\hline $\mathrm{SA}_{1.0 \mathrm{R}}$ & Kaya Zemin $\mathrm{T}=1.0 \mathrm{~s}$ Spektral İvmesi \\
\hline $\mathrm{SA}_{\mathrm{D} 1}$ & Kısa Periyot Tasarım İvme Değeri \\
\hline $\mathrm{SA}_{\mathrm{DS}}$ & Orta-Uzun Periyot Tasarım İvme Değeri \\
\hline$\sigma$ & Standart Sapma \\
\hline $\mathrm{T}$ & Periyot \\
\hline
\end{tabular}


Tasarım Spektrumu Parametreleri için Olasılıksal Sismik Tehlike Analizlerine ...

$\begin{array}{ll}\mathrm{T}_{0} & \text { Sabit İvme Platosu Köşe Periyodu } \\ \mathrm{T}_{\mathrm{A}} & \text { Sabit İvme Platosu Köşe Periyodu } \\ \mathrm{T}_{\mathrm{B}} & \text { Sabit İvme Platosu Köşe Periyodu } \\ \mathrm{T}_{\mathrm{C}} & \text { Sabit İvme Platosu Köşe Periyodu } \\ \mathrm{T}_{\mathrm{D}} & \text { Uzun Periyoda Geçiş Periyodu } \\ \mathrm{TDY}_{07} & \text { Türk Deprem Yönetmeliği } \\ \mathrm{T}_{\mathrm{L}} & \text { Uzun Periyoda Geçiş Periyodu } \\ \mathrm{T}_{\mathrm{R}} & \text { Dönüş Periyodu } \\ \mathrm{T}_{\mathrm{S}} & \text { Sabit İvme Platosu Köşe Periyodu } \\ \mathrm{U} & \text { Tanımlanmamış Fay } \\ \mathrm{V}_{\mathrm{S} 30} & \text { Zemin Kesme Dalgası Hızı } \\ \text { YHTD } & \text { Yer Hareketi Tahmin Denklemi } \\ \mathrm{Z1} & \text { TDY07 Zemin Sınıfı } \\ \mathrm{Z} 2 & \text { TDY07 Zemin Sınıfı } \\ \mathrm{Z} 3 & \text { TDY07 Zemin Sınıfı } \\ \mathrm{Z} 4 & \text { TDY07 Zemin Sınıfı }\end{array}$

\section{Teşekkür}

Bu çalışmanın yazarı TÜBITTAK - BIDDEB Yurtdışı Doktora Sonrası Araştırma Burs Programı kapsamında desteklenmiştir. Bu çalışma TÜBİTAK - 213M245 kodlu 1002 Hızlı Destek Programı araştırma projesi kapsamında yapılan çalışmaların bir bölümünü teşkil etmektedir. Yazar Prof. Dr. Sinan Akkar' a bu çalışma ile ilgili yapıcı yorumları ve geri bildirimleri için ve iki hakeme de çalışmayı değerlendirerek kalitesinin artmasına yardımcı oldukları için teşekkür eder.

\section{Kaynaklar}

[1] Deprem Bölgelerinde Yapılacak Binalar Hakkında Yönetmelik (DBYBHY), T.C. Bayındırlık ve İskan Bakanlığı, Afet İşleri Genel Müdürlüğü, Deprem Araştırma Dairesi, http://www.deprem.gov.tr, Ankara, 2007.

[2] CEN, Eurocode 8: Design of structures for earthquake Resistance - Part 1: General rules, seismic actions, and rules for buildings, EN 1998-1:2004, Comité Européen de Normalisation, Brussels, 2004.

[3] Building Seismic Safety Council (BSSC), NEHRP Recommended Seismic Provisions For New Buildings and Other Structures: Part 1, Provisions, Federal Emergency Management Agency (FEMA-P-1050-1), Washington, D.C., 2015.

[4] Newmark, N. M., Hall, W. J., Earthquake spectra and design, Earthquake Engineering Research Institute, Berkeley, California, 1982. 
[5] Rey, J., Faccioli, E., Bommer, J. J., Derivation of design soil coefficients (S) and response spectel shapes for Eurocode 8 using the European Strong-Motion Database, Journal of Seismology, 6, 547-555, 2002.

[6] Kalkan, E., Gülkan, P., Site-Dependent Spectra Derived from Ground Motion Records in Turkey, Earthquake Spectra, 20, 1111-1138, 2004.

[7] Pitilakis, K., Riga, E., Anastasiadis, A., Design spectra and amplification factors for Eurocode 8, Bulletin of Earthquake Engineering, 10, 1377-1400, 2012.

[8] Giardini, D., Woessner, J., Danciu, L., Mapping Europe's Seismic Hazard, EOS 95, 261-262, 2014.

[9] Seyhan, E., Stewart, J.P., Semi-Empirical Nonlinear Site Amplification from NGAWest2 Data and Simulations, Earthquake Spectra, 30, 1241-1256, 2014.

[10] Türkiye Bina Deprem Yönetmeliği (TBDY) Taslağı, T.C. Başbakanlık Afet ve Acil Durum Yönetimi Başkanlığı, Deprem Dairesi Başkanlığı, http://www.deprem.gov.tr, Ankara, 2016.

[11] Cotton, F., Scherbaum, F., Bommer, J. J., Bungum, H., Criteria for Selecting and Adjusting Ground-Motion Models for Specific Target Regions: Application to Central Europe and Rock Sites, Journal of Seismology, 10, 137-156, 2006.

[12] Bommer, J. J., Douglas, J., Scherbaum, F., Cotton, F., Bungum, H., Fäh, D., On the Selection of Ground-Motion Prediction Equations for Seismic Hazard Analysis, Seismological Research Letters, 81, 783-793, 2010.

[13] Özbey, C., Sarı, A., Manuel, L., Erdik, M., Fahjan, Y., An empirical attenuation relationship for northwestern Turkey ground motion using a random effects approach, Soil Dynamics and Earthquake Engineering, 24, 2, 115-125, 2004.

[14] Zhao, J. X., Zhang, J., Asano, A., Ohno, Y., Oouchi, T., Takahashi, T., Ogawa, H., Irikura, K., Thio, H. K., Somerville, P. G., Fukushima, Y., Attenuation relations of strong ground motion in Japan using site classification based on predominant period, Bulletin of the Seismological Society of America, 96, 3, 898-913, 2006.

[15] Cauzzi, C., E. Faccioli, Broadband (0.05 to $20 \mathrm{~s}$ ) prediction of displacement response spectra based on worldwide digital records, Journal of Seismology, 12, 4, 453-475, 2008.

[16] Abrahamson, N. A., Silva, W. J., Summary of the Abrahamson \& Silva NGA Ground Motion Relations, Earthquake Spectra, 24, 1, 67-97, 2008.

[17] Boore, D. M., Atkinson, G., Ground-Motion Prediction Equations for the Average Horizontal Component of PGA, PGV, and 5\%-Damped PSA at Spectral Periods between $0.01 \mathrm{~s}$ and $10.0 \mathrm{~s}$, Earthquake Spectra, 24, 1, 99-138, 2008.

[18] Campbell, K. W., Bozorgnia, Y., NGA ground motion model for the geometric mean horizontal component of PGA, PGV, PGD and 5\% damped linear elastic response spectra for periods ranging from 0.01 to $10 \mathrm{~s}$, Earthquake Spectra 24, 1, 139-171, 2008. 
Tasarım Spektrumu Parametreleri için Olasılıksal Sismik Tehlike Analizlerine ...

[19] Chiou, B. S.-J., Youngs, R. R., An NGA Model for the Average Horizontal Component of Peak Ground Motion and Response Spectra, Earthquake Spectra, 24, 1, 173-215, 2008.

[20] Akkar, S., Sandıkkaya, M. A., Bommer, J. J., Empirical Ground-Motion Models for Point- and Extended- Source Crustal Earthquake Scenarios in Europe and the Middle East, Bulletin of Earthquake Engineering, 12, 359-387, 2014.

[21] Bindi, D., Massa, M., Luzi, L., Ameri, G., Pacor, F., Puglia, R., Augliera, P., PanEuropean ground-motion prediction equations for the average horizontal component of PGA, PGV, and 5\%-damped PSA at spectral periods up to $3.0 \mathrm{~s}$ using the RESORCE dataset, Bulletin of Earthquake Engineering, 12, 391-430, 2014.

[22] Kale, Ö., Akkar, S., Ansari, A., Hamzehloo, H., A ground-motion predictive model for Iran and Turkey for horizontal PGA, PGV and 5\%-damped response spectrum: Investigation of possible regional effects, Bulletin of the Seismological Society of America, 105, 2a, 963-980, 2015.

[23] Nash, J. E., Sutcliffe, J. V., River flow forecasting through conceptual models: Part I A discussion of principles, Journal of Hydrology, 10, 282-290, 1970.

[24] Scherbaum, F., Cotton, F., Smit, P., On the Use of Response Spectral-Reference Data for the Selection and Ranking of Ground-Motion Models for Seismic-Hazard Analysis in Regions of Moderate Seismicity: The Case of Rock Motion, Bulletin of the Seismological Society of America, 94, 6, 2164-2185, 2004.

[25] Scherbaum, F., Delavaud, E., Riggelsen, C., Model selection in seismic hazard analysis: An information-theoretic perspective, Bulletin of the Seismological Society of America, 99, 6, 3234-3247, 2009.

[26] Kale, Ö., Akkar, S., A New Procedure for Selecting and Ranking Ground-Motion Prediction Equations (GMPEs): The Euclidean Distance-Based Ranking (EDR) Method, Bulletin of the Seismological Society of America, 103, 2a, 1069-1084, 2013.

[27] Danciu, L., Kale, Ö., Akkar, S., The 2014 Earthquake Model of the Middle East: ground motion model and uncertainties, Bulletin of Earthquake Engineering, doi:10.1007/s10518-016-9989-1, 2016.

[28] Stewart, J. P., Douglas, J., Javanbarg, M., Abrahamson, N. A., Bozorgnia, Y., Boore, D. M., Campbell, K. W., Delavaud, E., Erdik, M., Stafford, P. J., Selection of groundmotion prediction equations for the global earthquake model, Earthquake Spectra, 31, 1, 19-45, 2015.

[29] Kale, Ö., Akkar, S., A Ground-Motion Logic-Tree Scheme for Regional Seismic Hazard Studies, Earthquake Spectra, DOI 10.1193/051316EQS080M, 2017.

[30] Kale, Ö., Akkar, S., An Auxiliary Tool to Build Ground-Motion Logic-Tree Framework for Probabilistic Seismic Hazard Assessment, 3. Türkiye Deprem Mühendisliği ve Sismoloji Konferansı, İzmir, 2015. 
[31] Sesetyan, K., Demircioğlu, M.B., Duman, T.Y., Çan, T., Tekin, S., Azak, T.E., Fercan, Ö.Z., A probabilistic seismic hazard assessment for the Turkish territory: part I: the area source model, Bulletin of Earthquake Engineering, doi:10.1007/s10518016-0005-6, 2016.

[32] Demircioğlu, M.B., Sesetyan, K., Duman, T., Çan T., Tekin, S., Ergintav, S., Source zonation model for the seismic hazard assessment of The Turkish Territory: part II: fault source and background seismicity model, Bulletin of Earthquake Engineering, DOI 10.1007/s10518-017-0130-x, 2017.

[33] Risk Engineering, EZ-FRISK-Software for Ground Motion Estimation, Risk Engineering Inc., Boulder, Colorado, 2015.

[34] Sandıkkaya, M. A., Akkar, S., Bard, P. Y., A Nonlinear Site Amplification Model for the Next Pan-European Ground-Motion Prediction Equations, Bulletin of the Seismological Society of America, 103, 1, 19-32, 2013.

[35] Akkar, S., Kale, Ö., Türkiye sismik tehlike haritasının güncellenmesi ve yeni deprem yönetmeliği, 8. Ulusal Deprem Mühendisliği Konferansı, İstanbul, 2015. 
